Buca Eğitim Fakültesi Dergisi, 2021, Say1 51, s.304-326

Araştırma Makalesi
The Journal of Buca Faculty of

Education, 2021, Issue 51, p.304-326

Original Research

\title{
Türkiye ve Avustralya Sosyal Bilgiler 5. Sınıf Öğretim Programlarının Değerler Eğitimi Bağlamında Karşılaştırılması
}

\section{The Comparision of Turkish and Australian 5th Grade Social Science Curricula in The Context of Values Education}

\author{
Saadet Aylin $Y A \breve{G} A N^{1}$ \\ ${ }^{1}$ Dr., Eğitim Bilimleri Bölümü, Eğitim Fakültesi, Tokat Gaziosmanpaşa Üniversitesi, Türkiye, \\ saadetaylin.yagan@gop.edu.tr, (https://orcid.org/0000-0001-7429-7415)
}

Geliş Tarihi: 29/12/2020

Kabul Tarihi: 14/06/2021

\section{ÖZ}

$\mathrm{Bu}$ araştırmanın amacı, Türkiye ve Avustralya 5. sınıf sosyal bilgiler öğretim programlarının değerler eğitimi bağlamında karşılaştırılmasıdır. Araştırmada nitel araştırma yöntemi benimsenmiştir. Araştırma deseni doküman incelemesidir. Araştırma desenine uygun olarak veriler doküman inceleme tekniği ile toplanmıştır. Verilerin analizinde Schwartz değer sınıflandırması kullanılmıştır. Bu sınıflandırma, dört üst düzey değer ve bu üst düzey değerlerin altında gruplandırılan 12 değerden oluşmaktadır. Değişime açıklık, kendini geliştirme, muhafazakarlık ve öz-aşkınlık üst düzey değerlerdir. Öz-denetim, uyarılma, hazcılık, başarı, güç, saygınlık, güvenlik, geleneksellik, uyum, alçakgönüllülük, iyilikseverlik ve evrensellik sınıflandırmada yer alan değerlerdir. Verilerin analizinde betimsel analizden yararlanılmıştır. Bulgulara göre Türkiye'de uygulanan 5. sınıf sosyal bilgiler öğretim programında en fazla muhafazakarlık, en az öz aşkınlık üst düzey değerlerine ait kazanım yer almaktadır. Avustralya'da uygulanan öğretim programında ise kendini geliştirme üst düzey değeri en fazla sayıda kazanıma sahipken öz aşkınlık ve değişime açıklık üst düzey değerleri en az sayıda kazanıma sahiptir. Türkiye'de uygulanan öğretim programında öne çıkan değerler; güvenlik, güç ve öz-denetimdir. Avustralya'da uygulanan öğretim programında öne çıkan değerler; başarı, güç ve güvenliktir. Türkiye'de uygulanan öğretim programında saygınlık, uyum ve alçakgönüllülük değerlerini kapsayan bir kazanıma rastlanamazken Avustralya'da uygulanan öğretim programında uyarılma, hazcılık, saygınlık, uyum ve alçakgönüllülük değerlerine değinen kazanımlar bulunmamaktadır. Araştırmanın sonunda Türkiye'de uygulanan 5. sınıf sosyal bilgiler öğretim programında öz aşkınlık üst düzey değeriyle, saygınlık, uyum ve alçakgönüllülük değerlerine işaret eden kazanımlara yer verilebileceği önerisinde bulunulmuştur.

Anahtar Kelimeler: Avustralya, değerler eğitimi, karşılaştırmalı eğitim, sosyal bilgiler öğretim programı, Türkiye.

\begin{abstract}
The purpose of this research is to compare $5^{\text {th }}$ grade social studies curricula of Turkey and Australia in the context of values education. Qualitative research method has been adopted in the research. Research design is document review. In accordance with the research design, the data were collected by document analysis technique. Schwartz value classification was used in the analysis of the data. This classification consists of four higher order values and 12 values grouped under these higher order values. Openness to change, selfenhancement, conservation and self-transcendence are higher order values. Self-direction, stimulation, hedonism, achievement, power, face, security, tradition, conformity, humility, benevolence, and universality are the values included in the classification. Descriptive analysis was used to analyze the data. According to the findings, in Turkish $5^{\text {th }}$ grade social studies curriculum, the highest number of acquisitions belong to conservation higher order value, and the least number of acquisitions belong to self-
\end{abstract}


transcendence. In Australian curriculum, on the other hand self-development higher order value has the highest number of acquisitions whereas self-transcendence and openness to change higher order values have the least acquisitions. Security, power, and self-direction are prominent values of Turkish curriculum. Achievement, power, and security are prominent values of Australian curriculum. It could not be found any acquisitions related to face, conformity, and humility values in Turkish curriculum while there are not any acquisitions in the Australian curriculum that address stimulation, hedonism, face, conformity, and humility. At the end of the study, it has been suggested that Turkish $5^{\text {th }}$ grade social studies curriculum can include acquisitions that indicate the self-transcendence higher order value, and the values of face, conformity, and humility.

Keywords: Australia, comparative education, social sciences curriculum, Turkey, values education.

\section{GíRiș}

\subsection{Değerler ve Değerler Eğitimi}

Dünyanın farklı yerlerinde yaşamlarını sürdüren insan toplulukları yıllar içerisinde kendilerine ait kültürler oluşturmaktadır. Dil, din, sanat, tarih, alışkanlıklar ve geleneklerle birlikte değerler de kültürü oluşturan unsurlardandır (Kafadar, 2019; Oğuz, 2011). Değer, " bir şeyin önemini belirlemeye yarayan soyut ölçü, üstün nitelik, bir ulusun sahip olduğu sosyal, kültürel, ekonomik ve bilimsel değerleri kapsayan maddi ve manevi ögeler bütünü' (Türk Dil Kurumu, 2020) olarak tanımlanmaktadır. Başka bir tanımla değerler, "zihinsel olarak hedeflerimizi temsil etmek için kullanılan ve sosyal olarak arzu edilen kavramlardır" (Öztürk ve Kafadar, 2019, s. 273). Değerler neyin iyi neyin kötü olduğunu ayırt etmeye yarayan rehberler olarak da nitelendirilmektedir (Zengin, 2017b).

Değerler, toplumsal düzeni sağlama ve insan davranışlarını yönlendirmede önemli rol oynamaktadır (Çengelci, Hancı ve Karaduman, 2013). Dürüstlük, saygı, vefa, yardımseverlik, vatan sevgisi, merhamet gibi değerlerin benimsendiği toplumlarda insanlar arası olumlu ilişkiler kurulurken toplum bilinci de daha kuvvetli olmaktadır (Yazıc1, 2014). Değerler, seçim yapma, değerlendirme, karar alma, öncelikleri belirleme ve hayatı anlamlı kılma gibi konularda güdüleyici role sahiptir (Kardaş ve Cemal, 2017).

Toplumlara ve bireylere özgü pek çok değer bulunmaktadır. Bu değerlerden toplumsal ya da evrensel anlamda ön planda olanların belirlenebilmesi için farklı değer sinıflandırmaları yapılmaktadır. İlk değer sınıflandırmasının Spranger (1928) tarafından yapıldığı kabul edilir. Bu sınıflandırmada estetik, bilimsel, ekonomik, siyasi, sosyal ve dini değerlerden bahsedilmiştir (Akt: Keskin, 2016). Bir başka sınıflandırma Rokeach'a (1973) aittir. Rokeach, değerleri iki değer kümesinde sınıflandırmıştır. Bunlar amaçsal ve araçsal değerlerdir. Her biri 18 değer içermektedir. Amaçsal değerler, kişilerin hayatları boyunca ulaşmak istedikleri, arzu ettikleri en üst noktayı işaret eder. Farklı kültürlerde ya da farklı gruplarda değişkenlik gösterebilir. Araçsal değerler ise tercih edilen davranış tarzları ya da amaçsal değerlere ulaşma araçları olarak açıklanmıştır.

Dilmaç, Arıcak ve Cesur (2014), dokuz boyutlu bir değer sınıflandırması ortaya koymuşlardır. Bu sınıflandırmada, sosyal değerler, kariyer değerleri, entelektüel değerler, manevi değerler, materyalist değerler, insan onuruna ilişkin değerler, romantik değerler, özgürlükle ilgili değerler ve yiğitlik ile ilgili değerler ele alınmıştır. Johansson'ın (2018) sınıflandırması ise altı temel değer alanından oluşmaktadır. Yeterlik değer alanı diğer tüm değer alanlarıyla ilişkili olarak merkezde yer almaktadır. Diğer değer alanları; etik, güvenlik, kendini geliştirme, demokrasi, disiplin ve etkililiktir. Literatürde sıkça kullanılan ve bu araştırmanın da ölçütlerini oluşturan bir başka değerler sınıflandırması Schwartz, Cieciuch, Vecchione, Davidov, Fischer, Beierlein, Ramos, Verkasalo, Lönnqvist, Demirutku, Dirilen-Gumus ve Konty'e (2012) aittir. Bu sınıflandırma ilk olarak Schwartz (1992) tarafindan geliştirilmiş ve 20 ülkeyi kapsayan çalışmalar sonucu 10 değeri içeren bir sinıflandırma oluşturulmuştur. 
Sınıflandırma, daha kapsayıcı olması için Schwartz ve diğerleri (2012) tarafından tekrar ele alınmış 83 ülkeden veri toplanarak istatistiksel çalışmalar yapılmıştır. Yeni sınıflandırma; dört üst değer (değişime açıklık, kendini geliştirme, muhafazakarlık ve öz-aşkınlık), bu üst değerlere bağl1 12 değer ve bu değerlere bağl1 19 alt değerden oluşmaktadır (Tablo 3).

Değer sınıflandırmaları toplumların değer yapılarının ortaya çıkarılmasında ve hangi değerlerin yeni nesillere aktarılacağının belirlenmesinde etkili araçlardır. Her toplum kendi kültürünü ve değerlerini gelecek nesillere aktarmak ister. Bu aktarımı sağlamada en önemli görev eğitim kurumlarına düşmektedir (Merey, Kuş ve Karatekin, 2012). Eğitimden beklentiler, bilgi ve teknoloji aktarımının yanı sıra insanı ve insanlığa hizmeti ön plana koymak olarak güncellenmiştir. Bireylere toplumun değerlerinin, kültürünün, ahlaki, entelektüel ve duygusal birikiminin ve ortak mirasının benimsetilmesi; bireylerin sosyal yapıya aktif şekilde katılmalarının ve demokrasiyi özümsemelerinin sağlanmas1; bireylerin, kendileri kadar başkalarını da göz önünde bulundurarak farklı kişi ve kültürlere saygı duymalarının, etik, duygusal, fiziksel ve ruhsal açıdan bir dengeye ulaşabilmelerinin sağlanması eğitimin öncelikli amaçları arasında yer almaya başlamıştır (UNESCO, 2002). Belirtilen bu amaçların gerçekleştirilebilmesi için eğitim kurumlarında değerler eğitimine önem verilmesi gerekmektedir.

Değerler eğitimi; insanların kendi davranışlarının ve başkalarının davranışlarının altında yatan değerleri açığa kavuşturmak, bu değerler üzerinde düşünmek, değerlerin toplumsal refah üzerindeki etkilerini incelemek üzere yetki sahibi veya daha deneyimli kimseler tarafindan gerçekleştirilen faaliyetlerdir (Robb, 1998). Bir başka tanımla değerler eğitimi, doğrudan ya da dolaylı olarak çeşitli yöntem ve teknikleri kullanarak toplumun değerlerini genç kuşaklara öğretme çabasıdır (Ulusoy ve Dilmaç, 2016). Değerler eğitimi ahlaki düşünmeyle ilgilidir. Değerler eğitimiyle nasıl bir insan olunmalı ve nasıl davranılmalı sorularının cevabı aranır. Yaşamla ve diğer insanlara nasıl davranılması gerektiğiyle ilgili sosyal davranış kuralları ve prensipler ile kişilik özellikleri değerler eğitiminin ana konularıdır (Halstead ve Pike, 2006).

Literatürde değerler eğitiminin farklı boyutlarına odaklanan araştırmalara rastlamak mümkündür. Öğretim programlarını ya da ders kitaplarını değerler eğitimi bağlamında inceleyen araştırmalar (Aral ve Kadan, 2018; Çekin, 2012; Indriani, 2017; Özdemir, 2017; Pehlivan, Aydın ve İnnalı, 2017; Şahin ve Başgül, 2018), değerler eğitimiyle ilgili öğretmen, okul yöneticisi, veli ve öğrenci görüşlerini ortaya çıkarmayı amaçlayan araştırmalar (Akbaba, Kılcan ve Çepni, 2013; Özdemir, Boydak-Özan ve Akgün, 2017; Uzun ve Köse, 2017; Yazar, Özekinci ve Lala, 2017; Yıldırım, Becerikli ve Demirel, 2017) değerler eğitiminde öğretim yöntem ve teknikleriyle ilgili araştırmalar (Çelik ve Buluç, 2018; Fahyuni ve Bandono, 2017; Johansson, Brownlee, Cobb-Moore, Boulton-Lewis, Walker, ve Ailwood; Kaya, Günay ve Aydın, 2016), değerler eğitiminin öğrenciler üzerindeki etkilerini inceleyen araştırmalar (Bakan ve Şahin, 2018; Tulunay-Ateş, 2017) bunlardan bazılarıdır. Bu araştırmalar değerlendirildiğinde değerler eğitimiyle genellikle Türkçe, din kültürü ve ahlak bilgisi, tarih, hayat bilgisi ve sosyal bilgiler gibi derslerin ilişkilendirildiği görülmektedir. Bu araştırmada da sosyal bilgiler dersi üzerinde durulacaktır. Değerler ve değerler eğitimi; bireyi, toplumu, bireylerin toplumla ilişskisini düzenleyen ahlaki ve kültürel mirasın aktarılmasında rol oynayan olgulardır. Sosyal bilgiler dersi de toplum içerikli bir ders olması, tarihi ve kültürel ögeler barındırması, disiplinler arası bir yapıya sahip olması ve bu dersle öğrencilerin topluma uyum sağlamalarının hedeflenmesi nedenlerinden değer aktarımında önemli derslerin başında gelir (Kan, 2010). Literatürde değerler eğitimiyle ilgili araştırılan bir başka durum da farklı toplumlarda değer önceliklerinin değişip değişmediğidir. Değerler doğrudan kültür, gelenek, yaşam biçimi, toplum yapısı ve bakış açısıyla ilgili olduğundan farklı toplumlarda farklı değerleri benimseme durumu ortaya çıkabilmektedir. Literatürde değerler eğitimi bağlamında incelenen ya da Türkiye ile karşılaştırılan ülkeler arasında ABD, Kanada, Japonya, İngiltere ve Fransa yer almaktadır (bkz. Bektaş ve Zabun, 2019; Bursa ve Çengelci-Köse, 2017; Güneş ve Köse, 2016; Kafadar, 2019; Merey, Kuş ve Karatekin, 2012; Öztürk ve Kafadar, 2019; Schwartz, 2012). Avustralya ile ilgili 
olarak ülkedeki değerler eğitimini genel anlamda inceleyen bir araştırmaya rastlanmıştır (Zengin, 2017a). Zengin (2017a), araştırmasında Avustralya'daki değerler eğitiminin devlet destekli olması, değerlerle ilgili ulusal bir çerçevenin oluşturulmuş olması ve değerler eğitimiyle ilgili ülke genelinde farklı projeler yapılması özellikleri nedeniyle bu ülkedeki değerler eğitiminin incelenmesinin önemine vurgu yapmıştır. Literatür taraması sonucunda sosyal bilgiler dersiyle ilgili olarak Türkiye ve Avustralya değerler eğitimi karşılaştırmasına yer veren bir çalışmaya da rastlanamadığından karşılaştırma için Avustralya tercih edilmiştir. Bu araştırmada Türkiye ve Avustralya 5. sınıf sosyal bilgiler öğretim programı kazanımları değerler eğitimi bağlamında karşılaştırılmıştır. Her iki ülke için de 5. sınıf sosyal bilgiler dersi öğretim programı kazanımlarında hangi değerlerin benimsendiğinin ortaya çıkarılması, iki ülke arasındaki benzerlik ve farklılıkların tartışılabilmesi ve öğretim programı kazanımlarında yeteri kadar önem verilmeyen değerlerin belirlenmesi hususlarında çalışmanın literatüre katkı sunacağı düşünülmektedir. Araştırmaya teorik bir başlangıç oluşturması açısından bir sonraki başlıkta Türkiye ve Avustralya'da uygulanan sosyal bilgiler öğretim programlarının genel özellikleri ve değerler eğitimine genel yaklaşımları ile ilgili literatür taraması sunulmuştur.

\subsection{Türkiye ve Avustralya 5. Sınıf Sosyal Bilgiler Öğretim Programlarının Genel Özellikleri}

Türkiye'de öğretim programları Millî Eğitim Bakanlığı'na (MEB) bağlı Talim ve Terbiye Kurulu tarafından hazırlanır ve kurulun internet sitesinden erişime açılır. Ülkenin her yerinde aynı öğretim programları kullanılır. Avustralya öğretim programlarına ise Australian Curriculum, Assessment and Reporting Authority (ACARA) isimli kuruluşun sitesinden ulaşılabilmektedir. Bu sitede yer alan programlarda ülkenin her yerinde geçerli olan ortak özellikler belirlenir. Koşullara göre farklı yerleşim bölgelerinde yerel değişiklikler yapılabilir. Bu çalışmada Avustralya için ayrıca Avustralya Hükümeti Eğitim Bilimleri ve Öğretim Kurulu (Department of Education Science and Training) tarafindan oluşturulan Avustralya Okullarında Değerler Eğitimi Milli Çerçevesi'nden (National Framework for Values Education in Australian Schools) (2005) de yararlanılmıştır.

Türkiye'de uygulanan sosyal bilgiler öğretim programında 4-7. sinıflar genel özellikler bakımından bir arada ele alınırken her bir sınıf düzeyi için ayrı kazanımlar belirlenmiştir. Avustralya'da uygulanan öğretim programında sosyal bilgiler dersinin karşılığ bilimler olarak adlandırılmıştır. Genel özellikler bakımından K-7. sınıflar bir arada ele alınırken her bir sınıf düzeyi için ayrı kazanımlar belirlenmiştir.

Türkiye'de uygulanan 5. sınıf sosyal bilgiler öğretim programı yedi, Avustralya'da uygulanan 5. sınıf sosyal bilgiler öğretim programı ise dört öğrenme alanından oluşmaktadır. Türkiye'de uygulanan öğretim programındaki öğrenme alanları; birey ve toplum, kültür ve miras, insanlar, yerler ve çevreler, bilim, teknoloji ve toplum, üretim, dağıtım ve tüketim, etkin vatandaşlık ve küresel bağlantılardır. Avustralya'da uygulanan öğretim programındaki öğrenme alanları ise tarih, coğrafya, haklar ve vatandaşlık, ekonomi ve iş hayatıdır. Tablo 1'de öğrenme alanlarına ait kazanım sayıları sunulmuştur (ACARA, 2015; MEB, 2018).

Tablo 1. Türkiye ve Avustralya 5. Sınıf Sosyal Bilgiler Öğrenme Alanları

\begin{tabular}{lclc}
\hline Türkiye & Kazanım sayısı & Avustralya & Kazanım sayısı \\
\hline Birey ve toplum & 4 & Tarih & 7 \\
Kültür ve miras & 5 & Coğrafya & 9 \\
İnsanlar, yerler ve çevreler & 5 & Haklar ve vatandaşlık & 5 \\
Bilim, teknoloji ve toplum & 5 & Ekonomi ve iş hayatı & 9 \\
Üretim, dağıtım ve tüketim & 6 & & \\
Etkin vatandaşlık & 4 & & \\
Küresel bağlantılar & 4 & & Toplam=30
\end{tabular}


Tablo 1'de görüleceği üzere Türkiye ve Avustralya 5. sınıf sosyal bilgiler öğrenme alanları ve kazanımları karşılaştırıldığında Türkiye'de daha spesifik öğrenme alanları belirlendiği görülmektedir. Birey ve toplum, kültür ve miras, insanlar, yerler ve çevreler, bilim, teknoloji ve toplum, üretim, dağıtım ve tüketim, etkin vatandaşlık ve küresel bağlantılar Türkiye'de uygulanan öğretim programındaki öğrenme alanlarıdır. Avustralya'da uygulanan öğretim programındaki öğrenme alanları ise Tarih, coğrafya, haklar ve vatandaşlık ile ekonomi ve iş hayatıdır. Türkiye'de uygulanan öğretim programında öğrenme alanları detaylandırılmış olsa da Avustralya'da uygulanan öğretim programındaki öğrenme alanları bunları kapsar niteliktedir. Örneğin, tarih öğrenme alanı, birey ve toplum ile kültür ve miras öğrenme alanlarını; ekonomi ve iş hayatı öğrenme alanı ise bilim, teknoloji, toplum, üretim, dağıtım, tüketim ve küresel bağlantılar öğrenme alanlarını kapsamaktadır. Türkiye'de uygulanan öğretim programında en fazla kazanım; üretim, dağıtım ve tüketim öğrenme alanına aittir. Avustralya'da uygulanan öğretim programında en fazla kazanım, coğrafya ile ekonomi ve iş hayatı öğrenme alanlarına aittir. Her iki ülkenin kazanım sayıları birbirine yakındır.

Türkiye'de uygulanan sosyal bilgiler öğretim programında değerler, program perspektifini oluşturan ilkeler olarak tanımlanmaktadır. Değerler eğitiminde, geçmişe ve geleneklere bağlı olarak insanlığın ortak değerlerinin benimsetilmesi ve tüm bunların 1şığında günümüz ve geleceğin şekillendirilmesi amaçlanır. Yeni nesillerin etik açıdan uygun davranışlarda bulunabilmeleri için önemli görülen değerlerin ayrı bir ders ya da konu başlığı şeklinde değil öğretim programlarına entegre edilerek öğretilmesi ilkesi benimsenmiştir (MEB, 2018). Avustralya için ise etkili bir değer eğitiminin özellikleri; öğrencilerin temel insani değerleri anlamalarına ve uygulamalarına yardımcı olmak, demokratik yaşamı desteklemek ve okullarda çeşitliliğe önem vermek, toplumun değerlerini okullara yansıtmak, destekleyici bir öğretim ortamında değerleri öğrencilere keşfettirerek öğretmek, değer öğretiminde farklı model ve stratejilerden yararlanmak olarak sıralanmıştır (Department of Education Science and Training, 2005). İki ülkenin değerler eğitimine genel bakışı karşılaştırıldığında Türkiye'de uygulanan programın geleneklerine ve geçmişine bağlı bir değer anlayışı geliştirdiği Avustralya'da ise çeşitlilik ve demokrasi kavramlarının ön plana koyulduğu görülmektedir.

Türkiye ve Avustralya sosyal bilgiler dersi öğretim programı özel amaçlarının tamamı öğrencilere kazandırılması istenen değerlerle ilgilidir. İki ülkede ortak olarak kültürel kökenler, toplumsal değerler, ekonomi bilinci, çevre-insan ilişkisi, sosyal katılım ve etik ilkelerin önemsendiği görülmektedir. Türkiye'de uygulanan öğretim programında manevi değerlere yapılan vurgu Avustralya'da uygulanan öğretim programına nazaran fazladır. Vatan ve millet sevgisi, erdemli bir birey olma, milli ve manevi değerler Türkiye'de uygulanan öğretim programının manevi yönünü kuvvetlendirmektedir (ACARA, 2015; MEB, 2018).

Türkiye'de uygulanan sosyal bilgiler dersi öğretim programında öğrencilere kazandırılması istenen 10 kök değerden bahsedilmiştir. Ayrıca değer eğitimi başlığıyla öğrencilere kazandırılması hedeflenen 18 değer sıralanmıştır (MEB, 2018). Avustralya değerler çerçevesinde ise dokuz temel değer üzerinde durulmuştur (Department of Education Science and Training, 2005). Tablo 2'de Türkiye ve Avustralya sosyal bilgiler öğretim programlarında kazandırılmak istenen değerler sunulmuştur. 
Tablo 2. Türkiye ve Avustralya Sosyal Bilgiler Öğretim Programlarında Yer Alan Değerler

\begin{tabular}{llll}
\hline \multicolumn{2}{c}{ Türkiye } & \multicolumn{2}{c}{ Avustralya } \\
\cline { 1 - 2 } Tüm Değerler & & Kök Değerler & Adalet \\
Adalet & Eşitlik & Adalet & Dürüstlük ve güvenilirlik \\
Aile birliği & Özgürlük & Dürüstlük & Sorumluluk \\
Bağımsızlık & Saygı & Sorumluluk & Hak ve özgürlüklere sahip çıkma \\
Barış & Sevgi & Öz-denetim & Saygı \\
Bilimsellik & Sorumluluk & Saygı & İlgi ve merhamet \\
Çalışkanlık & Tasarruf & Yardımseverlik & Çaba \\
Dayanışma & Vatanseverlik & Sabır & Etik değerler, söz ve eylemde tutarlılık \\
Duyarlılık & Yardımseverlik & Dostluk & Anlayış, tolerans \\
Dürüstlük & Estetik & Vatanseverlik & \\
& & Sevgi & \\
\hline
\end{tabular}

Tablo 2'de görüleceği üzere Türkiye ve Avustralya sosyal bilgiler öğretim programlarında öğretilmesi beklenen temel değerler büyük ölçüde örtüşmektedir. Bu değerler daha çok topluma karşı sorumluluk ve iyi birer vatandaş olmayla ilgili değerlerdir. Türkiye'de uygulanan programda Avustralya'dan farklı ve ek olarak aile birliği, barış, bilimsellik, tasarruf, vatanseverlik ve estetik değerleri de vurgulanmıştır.

\subsection{Araştırmanın Amacı}

$\mathrm{Bu}$ araştırmanın amacı, Türkiye ve Avustralya 5. sınıf sosyal bilgiler öğretim programı kazanımlarının değerler eğitimi bağlamında karşılaştırılmasıdır. Karşılaştırma, Schwartz ve diğerleri (2012) tarafından oluşturulan değer sınıflandırması kullanılarak yapılmıştır. Araştırma soruları aşağıda sunulmuştur:

1. Türkiye ve Avustralya 5. sınıf sosyal bilgiler öğretim programı kazanımlarının değerler sınıflandırmasına göre dağılımı nasıldır?

2. Türkiye ve Avustralya 5. sınıf sosyal bilgiler öğretim programı kazanımlarının değişime açıklık üst değeri bağlamında benzer ve farklı yönleri nelerdir?

3. Türkiye ve Avustralya 5. sınıf sosyal bilgiler öğretim programı kazanımlarının kendini geliştirme üst değeri bağlamında benzer ve farklı yönleri nelerdir?

4. Türkiye ve Avustralya 5. sınıf sosyal bilgiler öğretim programı kazanımlarının muhafazakarlık üst değeri bağlamında benzer ve farklı yönleri nelerdir?

5. Türkiye ve Avustralya 5. sınıf sosyal bilgiler öğretim programı kazanımlarının özaşkınlık üst değeri bağlamında benzer ve farklı yönleri nelerdir?

\section{YÖNTEM}

\subsection{Araștırmanın Modeli}

Türkiye-Avustralya 5. sınıf sosyal bilgiler öğretim programlarının değer eğitimi bağlamında karşılaştırılmasını amaçlayan bu araştırmada nitel araştırma yöntemi ve doküman inceleme deseni kullanılmıştır. İki ülkenin dokümanları karşılaştırılırken tanımlayıcı yaklaşım benimsenmiştir. Tanımlayıcı yaklaşımda farklı ülkelerin karşılaştırılacak özelliklerine ait literatür taraması yapılır ve ülkeler arasındaki benzer ve farklı yönler ortaya çıkarılır (Ültanır, 2000). Bu araştırmada Türkiye ve Avustralya'nın sosyal bilgiler öğretim programı kazanımları Schwartz ve diğerlerinin (2012) değer sınıflandırması bağlamında karşılaştırılmıştır. Her iki ülkenin öğretim programlarıyla ilgili genel bilgiler ve değerler eğitimine bakış açıları literatür taramasıyla ortaya konmuş ardından öğretim programlarında yer alan kazanımların değerler bağlamında benzer ve farklı yönleri tartışılmıştır.

\subsection{Veri Toplama Tekniği}


Araştırmanın verileri doküman inceleme tekniği ile toplanmıştır. Doküman inceleme, "araştırılması hedeflenen olgu veya olaylar hakkında bilgi içeren yazılı materyallerin analizini kapsamaktadır" (Yıldırım ve Şimşek, 2016, s. 189). Bu araştırmada, Türkiye ve Avustralya 5. sınıf sosyal bilgiler öğretim programları ve her iki ülkede değerler eğitimiyle ilgili yayınlanmış resmi rapor ve bilimsel araştırmalar değerlendirilen dokümanları oluşturmuştur. Avustralya 2015 sosyal bilgiler öğretim programına ACARA resmi öğretim programı web sitesinden Türkiye 2018 sosyal bilgiler öğretim programına ise Millî Eğitim Bakanlığ 1 Talim ve Terbiye Kurulu web sitesinden erişilmiştir.

\subsection{Verilerin Analizi}

Verilerin analizinde Schwartz ve diğerlerinin (2012) değer sınıflandırması kullanılmıştır. Bu sinıflandırma 83 ülkeden geniş çaplı veri edinilerek ve kültürlerarası farklılıklar göz önünde bulundurularak oluşturulduğu için araştırmada tercih edilmiştir. Sınıflandırmadaki değerlerin kavramsal tanımları Schwartz (2017) tarafından yapılmıştır. Tablo 3'te sınıflandırmaya ait detaylar yer almaktadır.

Tablo 3. Schwartz Değer Sinıflandırması

\begin{tabular}{|c|c|c|c|}
\hline Üst değerler & Değerler & Alt Değerler & Kavramsal Tanım \\
\hline \multirow{4}{*}{ Değişime açıklık } & \multirow{2}{*}{ Öz-denetim } & Düşünce & $\begin{array}{l}\text { Bireyin fikir ve yeteneklerini } \\
\text { geliştirebilme özgürlüğ̈u }\end{array}$ \\
\hline & & Davranış & $\begin{array}{l}\text { Bireyin davranışlarını belirleme } \\
\text { özgürlüğ̈̈ }\end{array}$ \\
\hline & Uyarılma & & Heyecan, yenilik ve değişim \\
\hline & Hazcıllk & & Zevk ve duygusal doyum \\
\hline \multirow{4}{*}{$\begin{array}{l}\text { Kendini } \\
\text { gerçekleştirme }\end{array}$} & Başarı & & Sosyal standartlara göre başarılı olma \\
\hline & \multirow{2}{*}{ Güç } & Kişiler üzerinde & $\begin{array}{l}\text { İnsanları kontrol edebilme, hakimiyet } \\
\text { kurma }\end{array}$ \\
\hline & & $\begin{array}{l}\text { Kaynaklar } \\
\text { üzerinde }\end{array}$ & $\begin{array}{l}\text { Maddi ve sosyal kaynakları kontrol } \\
\text { edebilme }\end{array}$ \\
\hline & Saygınlık & & $\begin{array}{l}\text { İmajını koruma ve aşağılanmadan } \\
\text { kaçınma }\end{array}$ \\
\hline \multirow{5}{*}{ Muhafazakarlık } & \multirow[b]{2}{*}{ Güvenlik } & Kişisel güvenlik & Bireyin yakın çevresinde güvende olması \\
\hline & & Sosyal güvenlik & $\begin{array}{l}\text { Daha geniş çevrelerde güvenlik ve } \\
\text { istikrar }\end{array}$ \\
\hline & Geleneksellik & & $\begin{array}{l}\text { Kültürel, ailevi ve dini değerleri koruma } \\
\text { ve sürdürme }\end{array}$ \\
\hline & \multirow{2}{*}{ Uyum } & Kurallara uyma & $\begin{array}{l}\text { Resmi kurallara, yükümlülüklere ve } \\
\text { yasalara uyma }\end{array}$ \\
\hline & & Kişiler arası uyum & $\begin{array}{l}\text { Diğer bireyleri üzmekten ya da onlara } \\
\text { zarar vermekten kaçınma }\end{array}$ \\
\hline \multirow{6}{*}{ Öz-aşkınlık } & Alçakgönüllülük & & $\begin{array}{l}\text { Daha büyük ve önemli şeyler arasında } \\
\text { kendinin önemsizliğini anlama }\end{array}$ \\
\hline & \multirow{3}{*}{ Evrensellik } & Doğayı koruma & Doğal çevreyi koruma \\
\hline & & Eşitlik ve adalet & $\begin{array}{l}\text { Tüm insanlar için eşitlik, adalet ve } \\
\text { korunma kararlıllğı sergileme }\end{array}$ \\
\hline & & Tolerans & $\begin{array}{l}\text { Kendisinden farklı insanları anlama ve } \\
\text { kabullenme }\end{array}$ \\
\hline & \multirow[b]{2}{*}{ İyilikseverlik } & Yardım etme & İçinde yaşadığı grubun refahını gözetme \\
\hline & & Dürüstlük & $\begin{array}{l}\text { Grubun inanılır ve güvenilir bir üyesi } \\
\text { olma }\end{array}$ \\
\hline
\end{tabular}

Kaynak: Schwartz (2017)'den erişilmiş, araştırmacı tarafından Türkçeye çevrilmiştir.

Tablo 3'te görüleceği üzere Schwartz ve diğerlerinin (2012) sinıflandırmasında; özdenetim, uyarılma ve hazcılık değerlerini kapsayan değişime açıklık üst değeri, başarı, güç ve saygınlık değerlerini kapsayan kendini geliştirme üst değeri, güvenlik, geleneksellik ve uyum 
değerlerini kapsayan muhafazakarlık üst değeri ile alçakgönüllülük, evrensellik ve iyilikseverlik değerlerini kapsayan öz-aşkınlık değerleri yer almaktadır.

Verilerin analizinde betimsel analiz kullanılmıştır. Betimsel analizde "elde edilen veriler daha önceden belirlenen temalara göre özetlenir ve yorumlanır" (Yıldırım ve Şimşek, 2016, s. 239). Betimsel analiz, analiz için çerçeve oluşturulması, tematik çerçeveye göre verilerin işlenmesi, bulguların tanımlanması ve bulguların yorumlanması aşamalarından oluşur. Betimsel analiz için çerçeve oluşturma aşamasında araştırma soruları ya da kavramsal çerçeveden yola çıkılarak verilerin hangi temalar altında sunulacağı belirlenir. Verilerin işlenmesi aşamasında veriler okunur, düzenlenir, mantıklı bir bütün oluşturanlar bir araya getirilir. Sonraki aşamada düzenlenen veriler tanımlanır. Gerekirse doğrudan alıntılarla desteklenir. Son aşamada ise bulgular açıklanır, ilişkilendirilir ve anlamlandırılır (Yıldırım ve Şimşek, 2016, s. 240).

Bu çalışmada Türkiye ve Avustralya 5. sınıf sosyal bilgiler öğretim programı kazanımları karşılaş̧tırılırken Tablo 3'teki değerler analiz çerçevesini oluşturmuştur. Tabloda yer alan dört üst değer temalar olarak belirlenmiştir. İki ülkenin kazanımları Tablo 3'te yer alan kavramsal açıklamalar dikkate alınarak belirlenen temalar altında sınıflandırılmış son olarak bulgular yorumlanmış ve karşılaştırma yapılmıştır.

\subsection{Geçerlik ve Güvenirlik}

Nitel araştırmada geçerliği sağlamanın en önemli koşulu mümkün olduğunca araştırılan olguya yansız yaklaşmak ve araştırma sürecini açık, net ve ayrıntılı bir biçimde ortaya koyabilmektir. Ayrıca araştırmada oluşturulan kuramsal çerçeve ile bulguların örtüşmesi, veri toplanması ve analizi aşamalarında tutarlı olunması, bulguların birbirleriyle ve sonuçların da bulgularla anlamlı bir bütün oluşturması beklenir. Bulgular, diğer araştırmacılarca rahatlıkla değerlendirilebilecek şekilde sunulmalıdır (Miles ve Huberman, 1994; Yıldırım ve Şimşek, 2016). Nitel araştırmada güvenirliği sağlamak için ise veri kaynakları açık bir biçimde tanımlanmalıdır. Verilerin toplandığı ortamlardaki sosyal farklılıklar tartışılmalıdır. Kavramsal çerçeve, veri toplama ve veri analizi yöntemleri ayrıntılı olarak açıklanmalıdır. Betimsel olarak toplanan verilerin paylaşılması ve önceden belirlenmiş ve ayrıntılarıyla tanımlanmış ölçütlere göre veri analizi yapılması kullanılabilecek stratejilerdendir (LeCompte ve Goetz, 1982; Yıldırım ve Şimşek, 2016). Bu araştırmada geçerlik ve güvenirliği yani araştırmanın inandırıcılığını sağlamak adına araştırmanın tüm süreci detaylı ve açık bir şekilde aktarılmıştır. Türkiye ve Avustralya 5. sınıf sosyal bilgiler öğretim programları değerler eğitimi bağlamında karşılaştırıldığ 1 için kuramsal çerçevede iki ülkenin değerler eğitimi konusundaki benzer ve farklı yönleri tartışılmıştır. Verilerin analizinde Schwartz ve diğerlerinin (2012) değerler sınıflandırması ölçüt olarak kullanılmış, sınıflandırmada yer alan değerler ve bunlara ilişkin göstergeler sunulmuştur. Bulgular yine takip edilen sinıflandırmadaki ana değerler bağlamında anlamlı bir bütün oluşturacak şekilde organize edilmiştir. Sınıflandırılan kazanımlar sadece sayısal olarak verilmemiş, tüm kazanımlar açık haliyle sınıflandırılmıştır. Benzer bir araştırma yürütmek isteyen araştırmacılar için bulgular kolaylıkla değerlendirilebilecek şekilde sunularak yorumlanmıştır.

\section{BULGULAR}

\subsection{Türkiye ve Avustralya 5. Sınıf Sosyal Bilgiler Öğretim Programı Kazanımlarının Değerler Sınıflandırmasına Göre Dağılımı}

Tablo 4'te Schwartz ve diğerlerinin (2012) değer sınıflandırmasına göre Türkiye ve Avustralya 5. sınıf sosyal bilgiler öğretim programı kazanımlarının dağılımına yer verilmiştir. Şekil 1'de ise kazanımların sayısal dağılımı görsel olarak sunulmuştur. 
Tablo 4. Türkiye ve Avustralya 5. Sınıf Sosyal Bilgiler Öğretim Programı Kazanımlarının Değer Sınıflandırmasına Göre Dağılımı

\begin{tabular}{|c|c|c|c|c|c|}
\hline 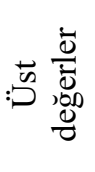 & 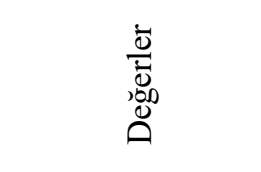 & 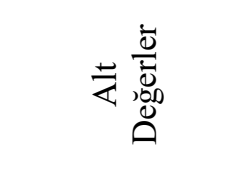 & 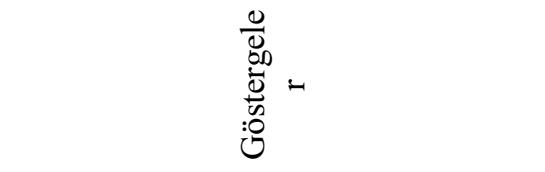 & 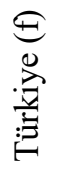 & 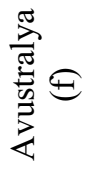 \\
\hline \multirow{5}{*}{ 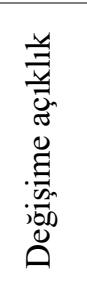 } & & Düşünce & \multirow{2}{*}{$\begin{array}{l}\text { Haklarının farkında olma } \\
\text { Edindiği bilgilerin doğruluğunu } \\
\text { sorgulama } \\
\text { Yeni fikirler üretme }\end{array}$} & & \\
\hline & Öz-denetim & Davranış & & 5 & 3 \\
\hline & Uyarılma & & Teknolojik yenilikleri benimseme & 2 & \\
\hline & Hazcılık & & Estetik & 1 & \\
\hline & & & Toplam & 8 & 3 \\
\hline \multirow{5}{*}{ 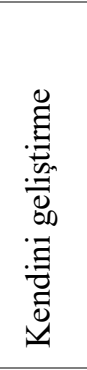 } & Başarı & & $\begin{array}{l}\text { Dersin gerektirdiği beceriler (grafik } \\
\text { okuma, oluşturma, harita okuma vs.) } \\
\text { Bilimsel düşünme }\end{array}$ & 3 & 10 \\
\hline & \multirow[b]{2}{*}{ Güç } & Kişiler üzerinde & \multirow{2}{*}{$\begin{array}{l}\text { Kaynakları tanıma, kullanma ve } \\
\text { koruma } \\
\text { Ekonomi bilinci } \\
\text { Maddi güç ve insan ilişkileri }\end{array}$} & \multirow[b]{2}{*}{5} & \multirow[b]{2}{*}{6} \\
\hline & & $\begin{array}{l}\text { Kaynaklar } \\
\text { üzerinde }\end{array}$ & & & \\
\hline & \multirow{2}{*}{\multicolumn{2}{|c|}{ Saygınlık }} & & & \\
\hline & & & Toplam & 8 & 16 \\
\hline \multirow{5}{*}{ 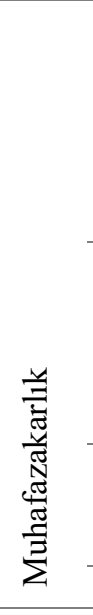 } & \multirow[b]{2}{*}{ Güvenlik } & $\begin{array}{l}\text { Kişisel } \\
\text { güvenlik }\end{array}$ & \multirow{2}{*}{$\begin{array}{l}\text { Gerçek ve sanal ortamda kişisel } \\
\text { güvenliğini koruma } \\
\text { Etkin vatandaşlık } \\
\text { Bir arada yaşayabilme } \\
\text { Afetlere ve çevre sorunlarına duyarlı } \\
\text { olma }\end{array}$} & \multirow[b]{2}{*}{7} & \multirow[b]{2}{*}{5} \\
\hline & & $\begin{array}{l}\text { Toplumsal } \\
\text { güvenlik }\end{array}$ & & & \\
\hline & Geleneksellik & & $\begin{array}{l}\text { Kültürel özellikleri bilme ve koruma } \\
\text { Kültürel mirası tanıma ve koruma } \\
\text { Tarih bilincine sahip olma } \\
\text { Milliyetçilik } \\
\text { Önemli şahsiyetleri tanıma }\end{array}$ & 4 & 3 \\
\hline & \multirow[t]{2}{*}{ Uyum } & $\begin{array}{l}\text { Kurallara uyma } \\
\text { Kişiler arası } \\
\text { uyum }\end{array}$ & & & \\
\hline & & & Toplam & 11 & 8 \\
\hline \multirow{6}{*}{ 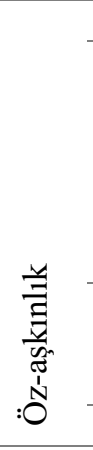 } & \multicolumn{2}{|l|}{ Alçakgönüllülük } & & & \\
\hline & \multirow[b]{2}{*}{ Evrensellik } & $\begin{array}{l}\text { Doğayı koruma } \\
\text { Eşitlik ve adalet }\end{array}$ & \multirow{2}{*}{$\begin{array}{l}\text { Doğal çevreye ilgi duyma ve koruma } \\
\text { Doğal çevre ile insan yaşamı arasında } \\
\text { ilişki kurma } \\
\text { Ortak doğal mirası tanıma } \\
\text { Farklı kültürleri tanıma ve saygı } \\
\text { duyma }\end{array}$} & \multirow[b]{2}{*}{4} & \multirow[b]{2}{*}{2} \\
\hline & & Tolerans & & & \\
\hline & \multirow{3}{*}{ İyilikseverlik } & İlgilenme & \multirow{3}{*}{$\begin{array}{l}\text { Görev ve sorumluluklarını yerine } \\
\text { getirme } \\
\text { Etiğe uygun davranma } \\
\text { Toplam }\end{array}$} & \multirow[b]{2}{*}{2} & \multirow[b]{2}{*}{1} \\
\hline & & Dürüstlük & & & \\
\hline & & & & 6 & 3 \\
\hline
\end{tabular}




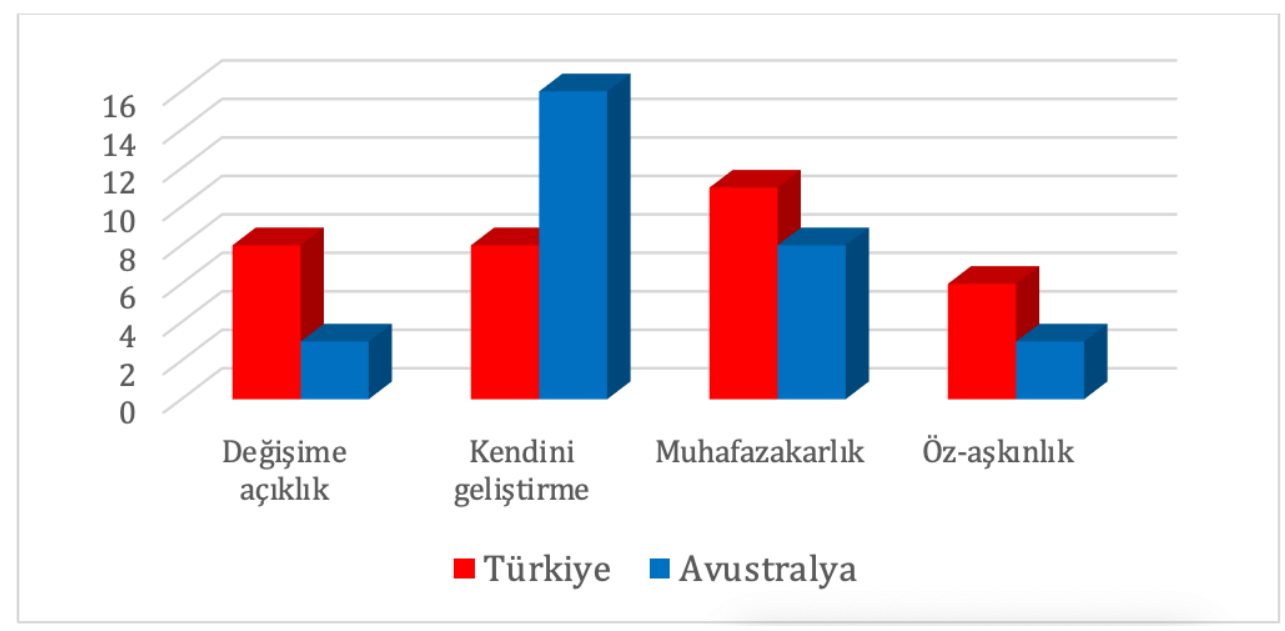

Şekil 1. Türkiye ve Avustralya 5. Sınıf Sosyal Bilgiler Öğretim Programı Kazanımlarının Değer Sinıflandırmasına Göre Dağılımı

Tablo 4 ve Şekil 1'den anlaşılacağı üzere Türkiye'de uygulanan 5. sınıf sosyal bilgiler öğretim programına ait kazanımlar en fazla muhafazakarlık üst değeri üzerinde durmaktadır $(f=11)$. En az kazanıma ise öz-aşkınlık üst değerinde rastlanmıştır $(f=6)$. Değerler bağlamında tablo incelendiğinde güvenlik değerinin ön plana çıktığı görülmektedir $(f=7)$. Bunu güç ve özdenetim değerleri $(f=5)$ takip etmektedir. Geleneksellik ve evrensellik değerleri de $(f=4)$ üzerinde durulan diğer değerlerdir. Türkiye'de uygulanan öğretim programında saygınlık, uyum ve alçakgönüllülük değerlerini kapsayan bir kazanıma rastlanamamıştır.

Avustralya'da uygulanan öğretim programına ait kazanımlar yoğun olarak kendini geliştirme üst değerinde gruplanmıştır $(f=16)$. Öz-aşkınlık ve değişime açıklık üst değerlerinde sınırlı sayıda kazanım göze çarpmaktadır $(f=3)$. Değerler bağlamında tablo incelendiğinde başarı değerinin üzerinde yoğunlaşıldığ 1 belirlenmiştir $(f=10)$. Bu değeri güç $(f=6)$ ve güvenlik $(f=5)$ değerleri izlemektedir. Avustralya'da uygulanan öğretim programında uyarılma, hazc1lı, saygınlık, uyum ve alçakgönüllülük değerlerine değinen kazanımlar bulunmamaktadır.

\subsection{Türkiye ve Avustralya 5. Sınıf Sosyal Bilgiler Öğretim Programı Kazanımlarının Değişime Açıklık Üst Değeri Bağlamında Karşılaştırılması}

Değişime açılklık üst değeri, bireylerin yeni fikirlere, eylemlere ve düşüncelere açık olma durumlarıyla ilgilidir. Bireysel düzeydeki değerleri içerir. Değişime açıklık üst değeri altında incelenen değerler; öz-denetim, uyarılma ve hazcılıktır (Schwartz ve diğerleri, 2012).

Öz-denetim değeri, düşünce ve davranışlarda kendini kontrol edebilme ve bağımsız hareket edebilme değerlerine işaret eder. Bu değere sahip bireyler kendi amaçlarını belirleyebilme, özgür düşünebilme, düşünceleri konusunda kendine güvenme özelliklerine sahiptir (Schwartz, 2017). Uyarılma değeri, heyecanlı aktivitelere katılma, rutinini bozabilme, yeniliklere açık olma ve değişimden hoşlanma özellikleriyle ilişkilidir (Schwartz, 2017). Hazcılık değeri ise yapılan etkinliklerden zevk alabilme ve duygusal doyum sağlama şeklinde açıklanmaktadır (Schwartz, 2017).

Tablo 5'te Türkiye ile Avustralya 5. sınıf sosyal bilgiler öğretim programı kazanımlarından örnekler değişime açıklık üst değeri bağlamında gruplandırılmıştır. 
Tablo 5. Türkiye ve Avustralya 5. Sınıf Sosyal Bilgiler Öğretim Programı Kazanımlarının Değişime Açıklık Üst Değeri Bağlamında Karşılaştırılması

\begin{tabular}{|c|c|c|}
\hline Üst değer & Değerler & Kazanım Örnekleri \\
\hline \multirow[t]{3}{*}{$\begin{array}{l}\text { Değişime } \\
\text { açıklik }\end{array}$} & $\begin{array}{l}\text { Öz- } \\
\text { denetim }\end{array}$ & $\begin{array}{l}\text { - "Çocuk olarak haklarından yararlanmaya ve bu hakların ihlal edildiği } \\
\text { durumlara örnekler verir." (Türkiye-Birey ve Toplum) } \\
\text { - "Sanal ortamda ulaştı̆̆ı bilgilerin doğruluk ve güvenilirliğini sorgular." } \\
\text { (Türkiye-Bilim, Teknoloji ve Toplum) } \\
\text { • "İs birliği yaparak üretim, dağıtım ve tüketime dayalı yeni fikirler } \\
\text { gelişstirir." (Türkiye-Üretim, Dağıtım ve Tüketim) } \\
\text { • "Çeşitli iletişsim kaynaklarını kullanarak haklar ve vatandaşlık } \\
\text { konularlyla ilgili görüşlerini, çıarımlarını ve fikirlerini sunar." } \\
\text { (Avustralya-Haklar ve Vatandaşlı) } \\
\text { • "Bir sorunun olası çözümlerini planlar ve bu çözüm yollarının ne tür } \\
\text { sonuçlar vereceğini düşünür." (Avustralya-Haklar ve Vatandaşllk) }\end{array}$ \\
\hline & Uyarılma & $\begin{array}{l}\text { - "Teknoloji kullanımının sosyalleşme ve toplumsal ilişkiler üzerindeki } \\
\text { etkisini tartışır." (Türkiye-Bilim, Teknoloji ve Toplum) } \\
\text { • "Ülkeler arasındaki ekonomik ilişkilerde iletişim ve ulaşım teknolojisinin } \\
\text { etkisini tartışır." (Türkiye-Küresel Bağlantılar) }\end{array}$ \\
\hline & Hazcılık & $\begin{array}{l}\text { - "Çevresindeki doğal varlıklar ile tarihî mekânlarl, nesneleri ve eserleri } \\
\text { tanıtır." (Türkiye-Kültür ve Miras) }\end{array}$ \\
\hline
\end{tabular}

Tablo 5'te görülebileceği gibi haklarının farkında olma, edindiği bilgilerin doğruluğunu sorgulama ve yeni fikirler üretme gibi göstergeleri içeren kazanımlar öz-denetim değeriyle ilişkilendirilmiştir. Öz-denetim değeriyle ilgili Türkiye'de uygulanan öğretim programında beş, Avustralya'da uygulanan öğretim programında üç kazanım yer almaktadır. Uyarılma değeri kazanımlardaki teknolojik yenilikleri benimseme göstergesiyle eşleştirilmiştir. Avustralya'da uygulanan öğretim programında uyarılma değeriyle ilgili kazanıma rastlanmazken Türkiye'de uygulanan öğretim programında iki kazanım bulunmaktadır. Hazcılık değeri ise kazanımlardaki estetik zevki ile eşleştirilmiştir. Türkiye'de uygulanan öğretim programında hazcılık değeriyle ilgili bir kazanım varken Avustralya' da uygulanan programda bu değerle ilişkilendirilebilecek bir kazanıma rastlanmamıştır.

\subsection{Türkiye ve Avustralya 5. Sınıf Sosyal Bilgiler Öğretim Programı Kazanımlarının Kendini Geliştirme Üst Değeri Bağlamında Karşılaştırılması}

Kendini geliştirme üst değeri, bireylerin ilgi alanları üzerine yoğunlaşan, bireysel refahlarıyla ilgili değerleri içerir. Öz-denetim değerleri gibi bireysel düzeydeki bir üst değerdir. Kendini geliştirme üst değeri altında incelenen değerler; başarı, güç ve saygınlıktır (Schwartz ve diğerleri, 2012).

Başarı değeri toplum nezdinde üstün bir nitelik olarak görülen akademik anlamda ya da iş hayatında başarıya odaklanır (Schwartz, 2017). Güç değeri, kişileri ve kaynakları kontrol altında tutarak gelebilecek tehditleri en aza indirmeyle ilgilidir (Schwartz, 2017). Saygınlık değeri ise bireyin toplum içindeki saygınlığının ve itibarın korunması (Schwartz, 2017) ile ilişkilendirilmiştir.

Tablo 6'da Türkiye ile Avustralya 5. sınıf sosyal bilgiler öğretim programı kazanımlarından örnekler kendini geliştirme üst değeri bağlamında gruplandırılmıştır. 
Tablo 6. Türkiye ve Avustralya 5. Sınıf Sosyal Bilgiler Öğretim Programı Kazanımlarının Kendini Geliştirme Üst Değeri Bağlamında Karşılaştırılması

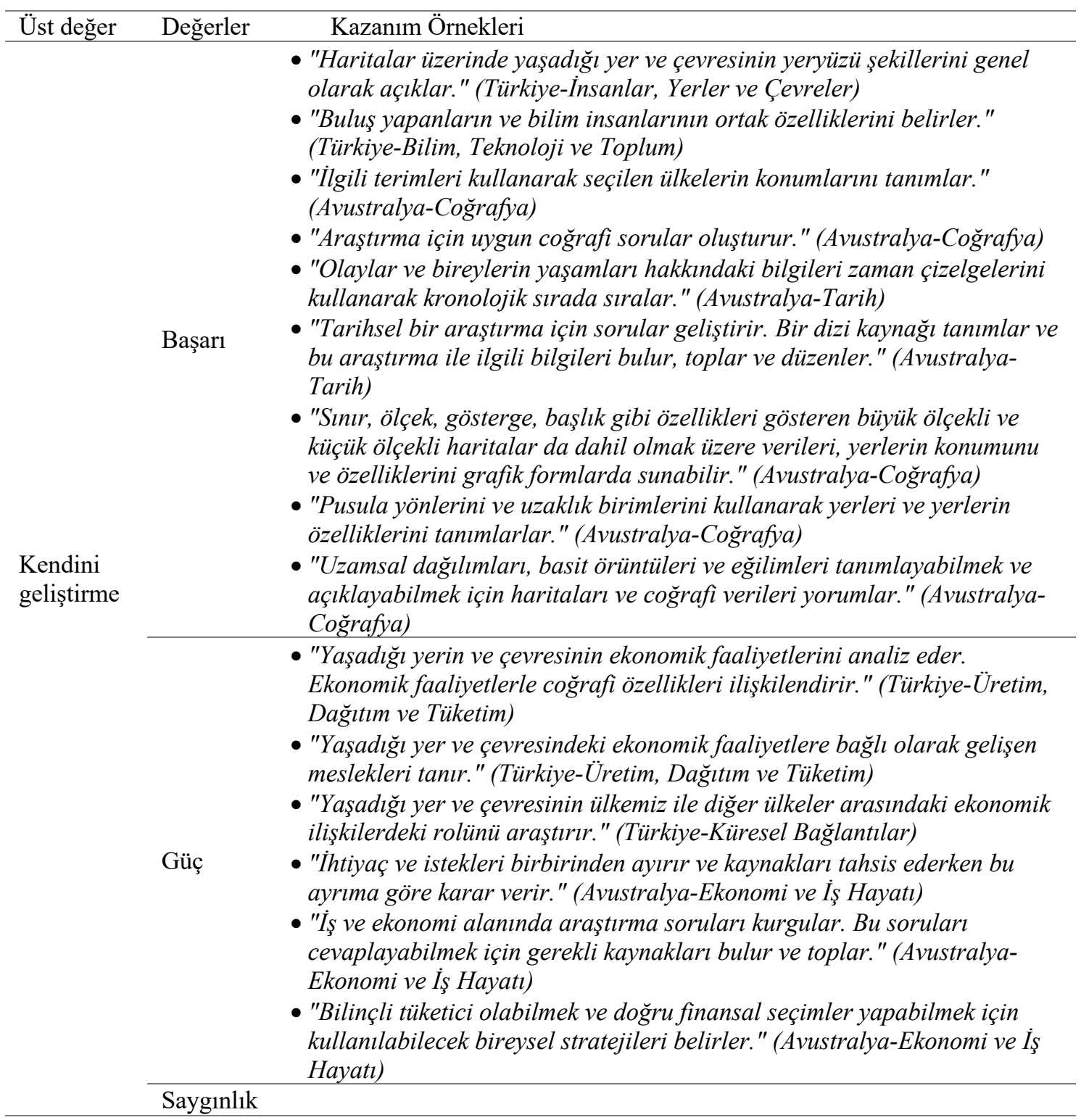

Tablo 6'da görüleceği üzere beceri odaklı kazanımlar başarı değeri altında gruplandırılmıştır. Dersin gerektirdiği beceriler (grafik okuma, oluşturma, harita okuma vs.) ve bilimsel düşünmeyle ilgili kazanımlar başarı değeriyle ilişkilidir. Avustralya'da uygulanan öğretim programında başarı değeriyle ilgili 10 kazanım bulunmaktayken Türkiye'de uygulanan öğretim programında üç kazanım yer almaktadır. Kaynakları tanıma, kullanma ve koruma, ekonomi bilinci, maddi güç ve insan ilişkileri gibi göstergeleri içeren kazanımlar güç değeri altında gruplandırılmıştır. Güç değerine ilişkin Türkiye' de uygulanan öğretim programında beş, Avustralya'da uygulanan öğretim programında altı değer yer almaktadır. Türkiye ve Avustralya 5. sınıf sosyal bilgiler öğretim programlarında saygınlık değeri ile ilgili kazanıma rastlanamamıştır.

\subsection{Türkiye ve Avustralya 5. Sınıf Sosyal Bilgiler Öğretim Programı Kazanımlarının Muhafazakarlık Üst Değeri Bağlamında Karşılaştırılması}

Muhafazakarlık üst değeri, bireylerin toplum huzuru için kendilerini kısıtlamaları, düzene uyum sağlamaları ve değişimden kaçarak var olanı korumak istemeleriyle ilgilidir. Toplumsal 
düzeydeki bir üst değerdir. Muhafazakarlık üst değeri altında incelenen değerler; güvenlik, geleneksellik ve uyumdur (Schwartz ve diğerleri, 2012).

Güvenlik değerinin kişisel güvenlik ve toplumsal güvenlik olmak üzere iki alt değeri vardır. Kişisel güvenlik, tehlikelerin farkında olma ve tehlikeden kaçınma ile ilgiliyken, toplumsal güvenlik, sosyal düzen ve yönetim istikrarı ile ilgilidir (Schwartz, 2017). Geleneksellik değeri, kültürel ve dini değerleri benimseme ve bu değerlere önem vermeyle ilişkilendirilir (Schwartz, 2017). Uyum değerinin kurallara uyma ve kişilerarası uyum olmak üzere iki alt değeri bulunmaktadır. Kurallara uyma resmi olarak belirlenen sorumlulukları yerine getirme ve yasalara uyma anlamına gelmektedir. Kişilerarası uyum ise toplum içerisinde diğer bireylerle uyum içerisinde yaşama, bireylere zarar vermekten kaçınma özelliklerini içerir (Schwartz, 2017).

Tablo 7'de Türkiye ile Avustralya 5. sınıf sosyal bilgiler öğretim programı kazanımlarından örnekler muhafazakarlık üst değeri bağlamında gruplandırılmıştır.

Tablo 7. Türkiye ve Avustralya 5. Sınıf Sosyal Bilgiler Öğretim Programı Kazanımlarının Muhafazakarlık Üst Değeri Bağlamında Karşılaştırılması

\begin{tabular}{|c|c|c|}
\hline Üst değer & Değerler & Kazanım Örnekleri \\
\hline \multirow{2}{*}{ 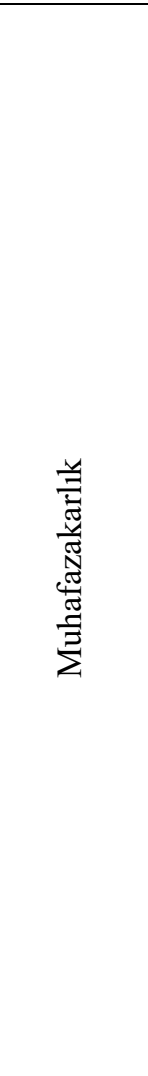 } & 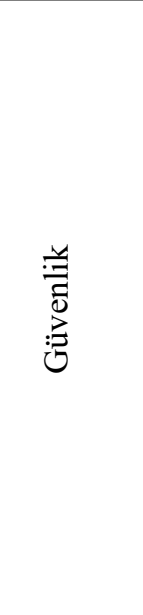 & $\begin{array}{l}\text { • "Sosyal Bilgiler dersinin, Türkiye Cumhuriyeti'nin etkin bir vatandaşı } \\
\text { olarak kendi gelişimine katkısını fark eder." (Türkiye-Birey ve Toplum) } \\
\text { • "Kültürel ögelerin, insanların bir arada yaşamasındaki rolünü analiz } \\
\text { eder." (Türkiye-Kültür ve Miras) } \\
\text { • "Yaşadiğı çevredeki afetlerin ve çevre sorunlarının oluşum nedenlerini } \\
\text { sorgular." (Türkiye-İnsanlar, Yerler ve Çevreler) } \\
\text { • "Sanal ortamı kullanırken güvenlik kurallarına uyar." (Türkiye-Bilim, } \\
\text { Teknoloji ve Toplum) } \\
\text { • "Coğrafi bir soruna ilişkin olası farklı çözüm yollarını bulur ve açıklar." } \\
\text { (Avustralya-Cografya) } \\
\text { • "Coğrafi bir soruna ilişkin eylem önerilerinde bulunur ve bu eylemlerin } \\
\text { - "Onuçlarını tespit eder." (Avustralya-Coğrafya) } \\
\text { katılmanın yollarını tanımlar ve konuyla ilgili problemlere karşı farklı } \\
\text { görüsler ortaya koyar." (Avustralya-Haklar ve Vatandaşlık) }\end{array}$ \\
\hline & 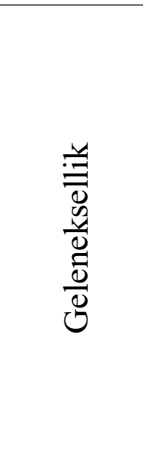 & $\begin{array}{l}\text { - "Somut kalıntılarından yola çıkarak Anadolu ve Mezopotamya } \\
\text { uygarlıklarının insanlık tarihine önemli katkılarını fark eder." (Türkiye- } \\
\text { Kültür ve Miras) } \\
\text { • "Günlük yaşamdaki kültürel unsurların tarihî gelişimini değerlendirir." } \\
\text { (Türkiye-Kültür ve Miras) } \\
\text { • "Millî egemenlik ve bağımsızlık sembollerimizden Bayrağımıza ve Istiklâl } \\
\text { Marşına değer verir." (Türkiye-Etkin Vatandaşlık) } \\
\text { • "Değişime neden olan insanların, olayların ve gelişmelerin önemini } \\
\text { tanımlar." (Avustralya-Tarih) } \\
\text { • "Geçmişte yaşamış farklı insanların deneyimlerini tanımlar." (Avustralya- } \\
\text { Tarih) }\end{array}$ \\
\hline
\end{tabular}

Uyum

Tablo 7'de görüleceği üzere gerçek ve sanal ortamda kişisel güvenliği koruma, etkin vatandaşlık, bir arada yaşayabilme, afetlere ve çevre sorunlarına duyarlı olma göstergelerini içeren kazanımlar güvenlik değeriyle ilişkilendirilmiştir. Türkiye'de uygulanan öğretim programında güvenlik değeriyle ilgili yedi kazanım bulunurken Avustralya'da uygulanan öğretim programında beș kazanım yer almaktadır. Kültürel özellikleri bilme ve koruma, kültürel mirası tanıma ve koruma, tarih bilincine sahip olma, milliyetçilik ve önemli şahsiyetleri tanımaya ilişkin kazanımlar geleneksellik değeri altında gruplandırılmıştır. Geleneksellik değeriyle ilgili Türkiye'de uygulanan öğretim programında dört, Avustralya'da uygulanan öğretim programında üç değer yer almaktadır. Uyum değeriyle ilgili ise Türkiye ve Avustralya 5. sınıf sosyal bilgiler öğretim programlarında herhangi bir kazanıma rastlanamamıştır. 


\subsection{Türkiye ve Avustralya 5. Sınıf Sosyal Bilgiler Öğretim Programı Kazanımlarının Öz-Aşkınlık Üst Değeri Bağlamında Karşılaştırılması}

Öz-aşkınlık üst değeri, başkalarının iyiliği için kendi çıkarlarını göz ardı etme şeklinde açıklanmıştır. Toplumsal düzeydeki bir üst değerdir. Öz-aşkınlık üst değeri altında incelenen değerler; alçakgönüllülük, evrensellik ve iyilikseverliktir (Schwartz ve diğerleri, 2012).

Alçakgönüllülük değeri, kendini merkeze alma ya da övünme gibi davranışlar sergilemek yerine öz-gelişimi ön plana almayı gerektirmektedir. Karşılık beklemeden katkıda bulunmak, daha önemli şeyler arasında bireyselliğin önemsizliğini kabullenmek davranışları bu değerle ilişkilidir (Schwartz, 2017). Evrensellik değeri, doğayı koruma, eşitlik ve adalet ile tolerans alt değerlerinden oluşmaktadır. Sosyal adalet, herkes için eşitlik, dünya barışı, güçsüzü ve dezavantajlıları koruma, dünyayı güzelleştirme, aynı fikirler paylaşılmasa bile diğer bireylere saygı duyma gibi özellikler evrensellik değeri altında incelenir (Schwartz ve diğerleri, 2012). İyilikseverlik değeri, yardım etme ve dürüstlük olmak üzere iki alt değere sahiptir. Toplumda güvenilir biri olma, topluma faydalı olma, sorumluluklarını yerine getirme, vefalı olma, başkalarının huzurunu gözetme gibi özellikler bu değerle ilişkilidir (Schwartz, 2017).

Tablo 8'de Türkiye ile Avustralya 5. sınıf sosyal bilgiler öğretim programı kazanımlarından örnekler öz-aşkınlık üst değeri bağlamında gruplandırılmıştır.

Tablo 8. Türkiye ve Avustralya 5. Sınıf Sosyal Bilgiler Öğretim Programı Kazanımlarının ÖzAşkınlık Üst Değeri Bağlamında Karşılaştırılması

\begin{tabular}{|c|c|c|}
\hline Üst değer & Değerler & Kazanım Örnekleri \\
\hline \multirow{3}{*}{ Öz-aşkınlık } & Alçakgönüllülük & \\
\hline & Evrensellik & $\begin{array}{l}\text { - "Yaşadı̆̆ı çevrede görülen iklimin, insan faaliyetlerine } \\
\text { etkisini, günlük yaşantısından örnekler vererek açılar." } \\
\text { (Türkiye-İnsanlar, Yerler ve Çevreler) } \\
\text { "Yaşadığı yer ve çevresindeki doğal özellikler ile beşerî } \\
\text { özelliklerin nüfus ve yerleşme üzerindeki etkilerine } \\
\text { örnekler verir." (Türkiye-Insanlar, Yerler ve Çevreler) } \\
\text { "Turizmin uluslararası ilişkilerdeki önemini açıklar. Farklı } \\
\text { ülke toplumlarının birbirini daha yakından tanımasının, } \\
\text { kültürrel zenginliklerini görmesinin ve karşılıklı ön } \\
\text { yargılarını fark etmesinin sağladığl kazançlar üzerinde } \\
\text { durulacaktır." (Türkiye-Kültürel Miras) } \\
\text { "Çeşitli ülkelerde bulunan ortak miras ögelerine örnekler } \\
\text { verir. Ülkemizden ve dünyanın farklı ülkelerinden örnekler } \\
\text { seçilerek ortak mirasın anlamı üzerinde durulur." } \\
\text { (Türkiye-Kültürel Miras) } \\
\text { "Farklı bakış açılarını tanımlayabilmek için kaynakların } \\
\text { kökenini ve amaçlarını belirler." (Avustralya-Tarih) } \\
\text { "Yerel ve ulusal ölçekte farklı yerlerin özelliklerini açılar. } \\
\text { Insanlar ve mekanların özelliklerini ve çevreyle ilişkilerini } \\
\text { tanımlarlar." (Avustralya-Coğrafya) }\end{array}$ \\
\hline & İyilikseverlik & $\begin{array}{l}\text { - "Sahip olduğu haklarının farkında olan bir birey olarak } \\
\text { katıldığı gruplarda aldığı rollerin gerektirdiği görev ve } \\
\text { sorumluluklara uygun davranır." (Türkiye-Birey ve } \\
\text { Toplum) } \\
\text { "Yaptı̆̆ çalışmalarda bilimsel etiğe uygun davranır." } \\
\text { (Türkiye-Bilim, Teknoloji ve Toplum) } \\
\text { "Değerlerin ve süreçlerin Avustralya demokrasisindeki } \\
\text { önemini ve Avustralya'nın hukuk sistemindeki farklı } \\
\text { insanların rollerini tanımlar." (Avustralya-Haklar ve } \\
\text { Vatandaşlık) }\end{array}$ \\
\hline
\end{tabular}


Tablo 8'de görüleceği üzere Türkiye ve Avustralya 5. sınıf sosyal bilgiler öğretim programlarında alçakgönüllülük değeriyle ilgili kazanıma rastlanamamıştır. Doğal çevreye ilgi duyma ve koruma, doğal çevre ile insan yaşamı arasında ilişki kurma, ortak doğal mirası tanıma ve farklı kültürleri tanıma-saygı duyma göstergelerini içeren kazanımlar evrensellik değeriyle iliş̧kilendirilmiştir. Evrensellik değeriyle ilgili Türkiye'de uygulanan öğretim programında dört, Avustralya'da uygulanan öğretim programında iki kazanım yer almaktadır. Görev ve sorumluluklarını yerine getirme ve etiğe uygun davranma göstergelerini kapsayan kazanımlar iyilikseverlik değeriyle ilişkilendirilmiştir. İyilikseverlik değeriyle ilgili Türkiye'de uygulanan öğretim programında iki, Avustralya'da uygulanan öğretim programında bir kazanım yer almaktadir.

\section{TARTIŞMA, SONUÇ VE ÖNERILER}

$\mathrm{Bu}$ araştırmada Türkiye ve Avustralya 5. sınıf sosyal bilgiler öğretim programı kazanımları Schwartz ve diğerleri (2012) tarafindan oluşturulan değer siniflandırmasına göre karşılaştırılmıştır. Türkiye ve Avustralya sosyal bilgiler dersinde değer öğretimi genel olarak ele alındığında her iki ülkede de değerlerin ayrı bir öğrenme alanı olarak değerlendirilmediği, programa yön veren ve kazanımlara entegre edilmiş bir anlayışla değer öğretiminin benimsendiği görülmektedir. Türkiye'de uygulanan öğretim programında geçmiş, günümüz ve gelecek arasındaki bağ vurgulanırken Avustralya'da uygulanan öğretim programında demokrasi ve çeşitlilik vurgusu ön plana çıkmaktadır. İki ülke arasındaki bu farkta sosyo-kültürel nedenler etkili olmuş olabilir. Türkiye üniter bir devlettir ve Türk tarihi boyunca çok sayıda Türk devleti kurulduğundan geçmiş, günümüz ve gelecek sıkı bir bağ içerisindedir. Avustralya ise dünyada kültür çeşitliliği açısından önde gelen ülkelerden biridir. Aborjinler ve göçler Avustralya'daki bu çeşitliliğe katkı sunmaktadır (Kurtuluş, 2018). Bahsedilen etkenler Türkiye'de uygulanan öğretim programında geçmişten güç alarak geleceğe yön verme Avustralya'da uygulanan programda ise farkl11ıklara sahip çıkarak bir arada yaşama değerlerinin öncelenmesine neden olmuş olabilir.

Türkiye ve Avustralya öğretim programlarında kök değerler ya da temel değerler olarak adlandırılan değerler yer almaktadır. Bu değerler iki programda büyük ölçüde örtüşür niteliktedir. Adalet, dürüstlük, sorumluluk, öz-denetim, saygı, yardımseverlik, sabır ve sevgi iki programdaki ortak temel değerlerdir. Temel değerlerin büyük ölçüde etkin vatandaşlık ve topluma karş1 sorumluluk üzerinde yoğunlaştığı görülmektedir. Temel değerlerin iki ülkede büyük oranda benzeşmesi küreselleşme ve bilgi-iletişim ağlarının yaygınlaşması ve farklı coğrafi bölgelerde bulunan ülkelerin etkileşim göstererek kültürel açıdan benzeşmeye başlamasıyla açıklanabilir. Bu benzeşmeyle birlikte evrensel ortak değerler ortaya çıkmaktadır (Kafadar, 2019). Bursa ve Çengelci-Köse (2017), Türkiye ve Kanada'nın 2005 yılı sosyal bilgiler öğretim programlarında (4-7. sınıf) yer alan değerleri karşılaştırdıkları çalışmalarında bu araştırmaya benzer olarak sorumluluk, adalet, saygı, hoşgörü ve duyarlılık değerlerinin her iki ülke için ortak değerler olduğu sonucuna ulaşmışlardır.

Temel değerler açısından Türkiye ve Avustralya'nın farklılaştığı değerler de vardır. Türkiye'de uygulanan öğretim programında dostluk ve vatanseverlik; Avustralya'da uygulanan öğretim programında ise etik değerler, söz ve eylemde tutarlılık ile anlayış ve tolerans bu değerlerdendir. Türkiye'de uygulanan öğretim programında ayrıca kök değerler dışında aile birliği, barış, bilimsellik, tasarruf ve estetik değerleri de vurgulanmıştır. Bu sonuç, ortak evrensel değerlerin yanı sıra her toplumun kendine özel şartlar dahilinde bazı değerlere önem verdiğini göstermektedir. Örneğin, tasarruf değeri gelişmekte olan bir ekonomiye sahip Türkiye (YıldırımSaçılık, 2019) için önem arz etmekte ve öğretim programında yer almaktayken Avustralya değerler çerçevesinde değinilen bir değer değildir. Bir başka örnek olarak vatanseverlik değeri, yakın geçmişinde savaşlar yaşamış ve halen terör tehdidi ile uğraşan Türkiye için yeni nesillere aktarılması istenen önemli bir değer olarak görülmektedir. Ayrıca vatanseverlik değerinin toplumda da önemli bir yansıması vardır. Veliler ve öğretmenler üzerinde yapılan çalışmalar 
vatanseverlik değerinin en fazla önemsenen değerlerden olduğunu göstermektedir (Beldağ, Özdemir ve Nalçac1, 2017; Karasu-Avcı, Faiz ve Turan, 2020; Yıldırım, Becerikli ve Demirel, 2017).

Schwartz ve diğerlerinin (2012) değer sinıflandırmasına göre Türkiye 5. sinıf sosyal bilgiler öğretim programı kazanımlarının üst değerler bağlamında sıralaması; muhafazakarlık, kendini geliştirme/değişime açıklık ve öz-aşkınlık şeklindedir. Kendini geliştirme ve değişime açıklık üst değerleriyle ilgili eşit sayıda kazanıma yer verilmiştir. Avustralya'da uygulanan öğretim programına ait kazanımların üst değerler açısından sıralaması ise kendini geliştirme, muhafazakarlık, değişime açıklık/öz-aşkınlıktır. Değişime açıklık ve öz-aşkınlık üst değerleriyle ilgili eşit sayıda kazanım yer almaktadır. Türkiye'de uygulanan öğretim programına ait kazanımlarda güvenlik, geleneksellik ve uyum değerlerinden oluşan muhafazakarlık üst değerine; Avustralya'da ise başarı, güç ve saygınlık değerlerinden oluşan kendini geliştirme üst değerine en fazla atıfta bulunulması Türkiye'de uygulanan öğretim programında topluma hizmetin nispeten öne çıkarıldığına Avustralya'da uygulanan öğretim programında ise bireysel gelişimin ön sıraya konduğuna işaret etmektedir. Bu bulguyu destekler şekilde Türkiye'de uygulanan öğretim programında bireysel yeteneklerin gelişimi desteklenmekle birlikte sosyal bilgiler dersinin asıl amacı topluma faydalı vatandaş yetiştirme olarak açıklanmıştır. Avustralya'da uygulanan öğretim programında ise öğrencilerin sorumlu birer vatandaş olması önemsenmekle birlikte bireysel beceri, davranış ve yetenekleri geliştirmek ön plandadır (ACARA, 2015; MEB, 2018). Her iki ülkede ortak olarak evrensellik, iyilikseverlik ve alçakgönüllülük değerlerini içeren öz-aşkınlık üst değeri ile ilgili kazanım sayısı azdır. Literatürde bu bulguları destekleyen araştırmalara rastlanmaktadır. Ecerkale ve Bayrak (2018), 7. sınıf Türkçe ders kitabında yer alan değerleri inceledikleri araştırmalarında alçakgönüllülük, merhamet ve hoşgörü gibi öz-aşkınlık üst değeri içerisinde yer alan değerlere az yer verildiği bulgusuna ulaşmışlardır. Aral ve Kadan (2018), okul öncesi öğretim programı kazanımlarını incelemişler ve kazanımlarda en az hoşgörü, özgürlük, eşitlik, dostluk ve adalet değerlerinin yer aldığını bulmuşlardır. Bulgularla kısmen örtüşen bir başka çalışma Gül'e (2017) aittir. Araştırmacının, 5. sınıf Türkçe ders kitabındaki değerleri incelediği araştırmasında öz-aşkınlık üst değerine ait bir değer olan evrensellik en sık rastlanan değerlerden olurken yine öz-aşkınlık değerlerinden olan iyilikseverlik en az yer verilen değerlerdendir. Avustralya'yla ilgili olarak öğretim programında en az kazanım öz-aşkınlık değerine ait olmasına rağmen Lee, Evers, Sneddon, Emeritus ve Schwartz (2019) tarafindan 1875 yaş arası Avustralyalılar üzerinde yapılan bir araştırmada en fazla öz-aşkınlık değerlerinin önemli görüldüğü bulgusuna ulaşılmıştır. Bulguların birbiriyle çelişmesi yaş etkenine bağlı olabilir. 5. sınıf düzeyi öz-aşkınlık değerlerinin kazandırılması için erken bir dönem olarak görülürken ilerleyen yaşlar için hazırlanan öğretim programlarında bu değerin önemi arttırılmış olabilir.

Münferit değerler bağlamında bulgular değerlendirildiğinde Türkiye'de uygulanan öğretim programında en fazla güvenlik, güç ve öz-denetim değerleriyle ilgili kazanımın yer aldığ 1 görülmektedir. Avustralya'da ise başarı değerinin üzerinde yoğunlaşıldığı belirlenmiştir. Güç ve güvenlik değerleri de sıkça işlenmiştir. Güvenlik ve güç değerleri Türkiye ve Avustralya öğretim programlarının ikisinde de ön plana çıkmaktadır. Güvenlik değerinin diğer değerlerin öğretilmesinde ön koşul olarak görülmesi bunun nedeni olabilir. Kişisel ve toplumsal güvenlik sağlanamadığı takdirde diğer değerlerin öğretimi mümkün olamayacaktır. Güç değeri kaynaklar ve kişiler üzerinde etkili olma anlamı taşımaktadır. Bu değerin ön plana çıkmasının sebebi gittikçe azalan kaynakların etkili kullanımının ve ekonomi bilincinin öğrencilere kazandırılması isteği olabilir. Literatürde bu sonuçları kısmen destekleyen araştırmalara rastlanmaktadır. Şakiroğlu (2020), 6. sınıf Türkçe ders kitaplarındaki değerleri incelediği araştırmasında güvenlik değerinin en sık rastlanan değerlerden olduğu bulgusuna ulaşmıştır. Özdemir (2017), ortaöğretim tarih dersi öğretim programlarını incelediği araştırmasında özdenetim değerinin önem verilen değerler arasında olduğunu belirtmiştir. Savaşkan (2017), Türkiye ve Azerbaycan' da kullanılan Edebiyat ders kitaplarında yer alan masalları değer iletimi bağlamında incelediği araştırmasında iki ülkede de en fazla güç değerine önem verildiği ancak güvenlik değerinin en az yer verilen değerlerden 
olduğunu ortaya koymuştur. Urfa (2019), ortaokul Türkçe ders kitaplarındaki değerleri incelediği araştırmasında güvenlik değerinin sık rastlanan değerlerden olduğunu, güç değerine orta düzeyde rastlandığını bulmuştur. Çekin (2012) ise ilköğretim din kültürü ve ahlak bilgisi öğretim programını incelediği araştırmasında bu araştırmadan farklı olarak kazanımlarda güç ve güvenlik değerlerine rastlanmadığı sonucuna ulaşmıştır.

Türkiye'de uygulanan öğretim programında saygınlık, uyum ve alçakgönüllülük değerlerine işaret eden bir kazanıma rastlanamamıştır. Hazcılık, uyarılma ve iyilikseverlik değerleriyle ilgili ise yeterli kazanım bulunmamaktadır. Avustralya'da uygulanan öğretim programında uyarılma, hazcılık, saygınlık, uyum ve alçakgönüllülük değerlerine değinen kazanımlar bulunmamaktadır. İyilikseverlik ve evrensellik değerleriyle ilgili ise yeterli sayıda kazanım yoktur. Urfa (2019) ve Çekin (2012), bu sonuçlara benzer olarak çalışmalarında hazcılık ve uyarılma değerlerine az sayıda rastlandığı ya da hiç rastlanmadığı bulgularına ulaşmışlardır. Kafadar'ın (2019), sosyal bilgiler dersi değer öğretiminde Türkiye, ABD ve Fransa'y1 karşılaş̧ırdığı araştırmasındaki sonuçlar da bu bulguları destekler niteliktedir. İki çalışma birlikte değerlendirildiğinde farklı kültürlerde de olsalar öğretim programlarında benzer değerlerin eksik kaldığı sonucu çıkarılabilir.

Sonuç olarak iki ülke karşılaştırıldığında Avustralya'da uygulanan öğretim programında beceri temelli kazanımların çokluğu dikkat çekmektedir. Melbourne deklarasyonu bu bulguyu destekler şekilde öğretim programının tutum, davranış ve bu tutumlarla davranışları uygulama üzerine yoğunlaştığını oysa net bir biçimde değerlerin kazandırılmasına yer verilmesi gerektiğini belirtmiştir (Reynold, 2018). Türkiye'de uygulanan öğretim programında ise değerlerin kazanımlarla çok iyi şekilde örtüştüğü görülmektedir. Her bir kazanım bir değerle eşleştirilebilmektedir. Kazanımların atıfta bulunduğu değerler Avustralya'ya göre daha çeşitlidir.

\section{1. Öneriler}

- Araştırma sonuçlarına göre 5. sınıf sosyal bilgiler dersi öğretim programında öz-aşkınlık değerine değinen yeterli sayıda kazanım yer almamaktadır. Bu nedenle kazanımlar özaşkınlık değerleri de göz önünde bulundurulacak şekilde güncellenebilir.

- Araştırma sonuçlarına göre 5. sınıf sosyal bilgiler öğretim programında saygınlık, uyum, alçakgönüllülük, hazcılık, uyarılma ve iyilikseverlik değerlerinin bazılarıyla ilgili kazanım bulunmamakta, bazılarıyla ilgili de yetersiz sayıda kazanım bulunmaktadır. $\mathrm{Bu}$ değerler göz önünde bulundurularak kazanımlar yeniden ele alınabilir.

- Farklı sınıf düzeylerindeki değer öncelikleri incelenebilir.

- Farklı değer sınıflandırmaları kullanılarak öğretim programlarında eksik bırakılan değerler saptanabilir.

- Türkiye ile farklı ülkeler değerler eğitimi bağlamında karşılaştırılabilir.

\section{KAYNAKÇA}

Akbaba, B., Kılcan, B. ve Çepni, O. (2013). The effect of 2011 Van earthquake on 8th grade students' value rankings. Mevlana International Journal of Education, 3(4), 75-85. Doi: 10.13054/mije.13.39.3.4

Aral, N. ve Kadan, G. (2018). 2013 Okul öncesi eğitim programının değerler eğitimi bağlamında incelenmesi. Erken Çocukluk Çalışmaları Dergisi, 2(1), 113-131. Doi: 10.24130/eccdjecs. 196720182159

Australian Curriculum, Assessment and Reporting Authority-ACARA. (2015). Australian curriculum. [Web-site]. https://www.australiancurriculum.edu.au/f-10curriculum/mathematics/ adresinden erişilmiş̧ir. 
Bakan, T. ve Şahin, H. (2018). Değerler eğitim programının anasınıfına devam eden çocukların değer kazanımı üzerine etkisinin çocuk görüşlerine göre incelenmesi. İnsan ve Toplum Bilimleri Dergisi, 12(2), 121-140. Doi: 10.16947/fsmia.502217

Bektaş, Ö. ve Zabun, E. (2019). Vatandaşlık eğitiminde değerler karşılaştırması: Türkiye ve Fransa. Dĕgerler Ĕgitimi Dergisi, 17(37), 247-289. Doi: 10.34234/ded.512221

Beldağ, A., Özdemir, Ü. ve Nalçacı, A. (2017). Sosyal bilgiler dersi öğretim programında yer alan değerlerin kazandırılmasına ilişkin veli görüşleri. Kırıkkale Üniversitesi Sosyal Bilimler Dergisi, $\quad 7(2), \quad 317-328 . \quad$ https://dergipark.org.tr/tr/pub/kusbd/issue/30549/322928 adresinden erişilmiştir.

Bursa, S. ve Çengelci-Köse, T. (2017). Türkiye ve Kanada sosyal bilgiler öğretim programlarının değerler eğitimi bakımından karşılaştırılması. Anadolu Journal of Educational Sciences International, 7(2), 338-372. Doi: 10.18039/ajesi.333738

Çekin, A. (2012). Değer açısından ilköğretim din kültürü ve ahlak bilgisi dersi kazanımları: Bir içerik analizi. Dinbilimleri Akademik Araştırma Dergisi, 12(2), 105-119. https://dergipark.org.tr/en/download/article-file/52245 adresinden erişilmiştir.

Çelik, Ö. ve Buluç, B. (2018). Disiplinler arası yaklaşımla değer öğretiminde yaratıcı drama yönteminin kullanılması. Erzincan Üniversitesi Eğitim Fakültesi Dergisi, 20(1), 67-88. Doi: 10.17556/erziefd.325878

Çengelci, T., Hancı, B. ve Karaduman, H. (2013). Okul ortamında değerler eğitimi konusunda öğretmen ve öğrenci görüssleri. Değerler Eğitimi Dergisi, 11(25), 33-56. https://dergipark.org.tr/tr/pub/ded/issue/29175/312420 adresinden erişilmiştir.

Değer. (2020). Türk Dil Kurumu güncel Türkçe sözlük içinde. https://sozluk.gov.tr/?kelime=millî\%20değer adresinden erişilmiştir.

Department of Education Science and Training-DEST. (2005). National framework for values education in Australian schools. Canberra: DEST.

Dilmaç, B., Arıcak, O. T. ve Cesur, S. (2014). A validity and reliability study on the development of the values scale in Turkey. Educational Sciences: Theory and Practice, 14(5), 16611671. Doi: 10.12738/estp.2014.5.2124

Ecerkale, N. ve Bayrak, Ö. (2018). Türkçe 7. sınıf ders kitabındakı metinlerin değerler bağlaminda incelenmesi. The Journal of International Lingual Social and Educational Sciences, 4(2), 277-287. https://dergipark.org.tr/en/pub/jilses/issue/41927/376352 adresinden erişilmiştir.

Fahyuni, E. F., and Bandono, A. (2017). The use of value clarification technique-based- picture story media as an alternative media to value education in primary school. Harmonia: Journal of Arts Research and Education, 17(1), 68-74. Doi: 10.15294/harmonia.v17i1.7469

Gül, M. (2017). Türkçe ders kitabındaki metinlerin (5. sınıf) değerler eğitimi yaklaşımıyla incelenmesi. Erciyes Journal of Education, 1(1), 59-78. https://dergipark.org.tr/tr/download/article-file/370781 adresinden erişilmiştir.

Güneş, F. ve Köse, N. (2016, Nisan). Japonya ve İngiltere'de değerler eğitiminin incelenmesi. Eğitimde Gelecek Arayışları: Dünden Bugüne Türkiye'de Beceri, Ahlak ve Değerler Eğitimi Uluslararas1 Sempozyumu'nda sunulan bildiri, Bartın. https://www.atam.gov.tr/wp-content/uploads/E\%c4\%9e\%c4\%b0T\%c4\%b0MDEGELECEK-ARAYI\%c5\%9eLARI-C\%c4\%b0LT-21.pdf adresinden erişilmiştir.

Halstead, J. M. and Pike, M. A. (2006). Citizenship and moral education: Values in action. Cornwall: Routledge. 
Indriani, D. E. (2017). Character education based on Pancasila values through curriculum 2013 on primary education children in Madura. Jurnal Pendidikan Dasar Indonesia, 2(1), 13$17 . \quad$ Retrieved https://journal.stkipsingkawang.ac.id/index.php/JPDI/article/view/312/340

from:

Johansson, E. (2018). The heart of values education in early childhood: Key issues and patterns. E. Johansson and A. Emilson (Eds). Values education in early childhood settings. Concepts, approaches and practices içinde (s.33-54). Switzerland: Springer.

Johansson, E., Brownlee, J., Cobb-Moore, C., Boulton-Lewis, G., Walker, S., and Ailwood, J. (2011). Practices for teaching moral values in the early years: A call for a pedagogy of participation. Education, Citizenship and Social Justice, 6(2), 109-124. Doi: 10.1177/1746197910397914

Kafadar, T. (2019). Türkiye, ABD ve Fransa'nın sosyal bilgiler ögretim programları ve ders kitaplarının değerler eğitimi boyutunda karşılaş̧ırılması. (Doktora tezi). https://tez.yok.gov.tr/UlusalTezMerkezi// adresinden erişilmiştir (Tez No: 537775).

Kan, Ç. (2010). Sosyal bilgiler dersi ve değerler eğitimi. Milli Eğitim Dergisi, 187, 138-145. https://dergipark.org.tr/en/download/article-file/442731 adresinden erişilmiştir.

Karasu-Avcı, E., Faiz, M. ve Turan, S. (2020). Etkili vatandaşlık eğitiminde değerler eğitimi: Sosyal bilgiler öğretmenlerinin düşünceleri. Değerler Eğitimi Dergisi, 18(39), 263-296. Doi: $10.34234 /$ ded.655916

Kardaş, M. ve Cemal, S. (2017). Değerler eğitimi ve Türkçe öğretiminde değer eğitimi üzerine yapılan araștırmalara ilişkin kaynakça denemesi. Karadeniz Sosyal Bilimler Dergisi, 9(16), 383-412. https://dergipark.org.tr/tr/pub/ksbd/issue/31387/344595 adresinden erişilmiştir.

Kaya, Y., Günay, R. ve Aydın, H. (2016). Okul öncesi eğitimde drama yöntemi ile işlenen değerler eğitimi derslerinin farkındalık düzeyi üzerindeki etkisi. Sakarya University Journal of Education, 6(1), 23-38. Doi: http://dx.doi.org/

Keskin, Y. (2016). Değer sınıflaması üzerine aksiyonel bir deneme. Turkish Studies International Periodical for the Languages, Literature and History of Turkish or Turkic, 11(3), 14851510. Doi: $10.7827 /$ TurkishStudies. 9467

Kurtuluş, F. (2018). Çok kültürlü bazı ülkelerde eğitim politikaları ve öğretmen eğitimi. Anadolu Üniversitesi Eğitim Fakültesi Dergisi, 2(3), 178-195. https://dergipark.org.tr/tr/download/article-file/540738 adresinden erişilmiştir.

LeCompte, M. D., and Goetz, J. P. (1982). Problems of reliability and validity in ethnographic research. Review of Educational Research, 52(1), 31-60 https://www.researchgate.net/ adresinden erişilmiştir.

Lee, J., Evers, U., Sneddon, J., Emeritus, O. R., and Schwartz, S. (2019). What do we value? The University of Western Australia Centre for Human and Culture Values veri tabanından http://whatdowevalue.com.au/wp-content/uploads/2019/03/Values-Report-Final-2019-

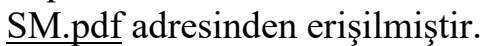

Merey, Z., Kuş, Z. ve Karatekin, K. (2012). Türkiye ve ABD ilköğretim sosyal bilgiler öğretim programlarının değerler eğitimi açısından karşılaştırılması. Kuram ve Uygulamada Eğitim Bilimleri, $\quad 12(2)$ 1613-1632. https://www.idealonline.com.tr/IdealOnline/searchResults.xhtml adresinden erişilmiştir.

Miles, M, B., and Huberman, A. M. (1994). Qualitative data analysis: An expanded sourcebook. $\left(2^{\text {nd }}\right.$ ed). Thousand Oaks, CA: Sage.

Millî Eğitim Bakanlığı, (2018). Sosyal bilgiler dersi ögretim programı. Ankara: MEB. 
Oğuz, E. S. (2011). Toplum bilimlerinde kültür kavram1. Hacettepe Üniversitesi Edebiyat Fakültesi Dergisi, 28(2), 123-139. https://dergipark.org.tr/tr/pub/huefd/issue/41213/505402 adresinden erişilmiştir.

Özdemir, K. (2017). Tarih dersi öğretim programının değerler eğitimi açısından incelenmesi, International Journal of Education Technology and Scientific Researches, 2(4), 240-257. http://www.ijetsar.com/Makaleler/1054522700 4.\%20240257\%20kamuran\%20\%c3\%b6zdemir.pdf adresinden erişilmiştir.

Özdemir, T., Boydak-Özan, M. ve Akgün, M. (2017). Öğretmen görüşleriyle değerler eğitimi odaklı eğitim denetimi. Bartın Üniversitesi Ë̆itim Araştırmaları Dergisi, 1(1), 35-52. https://dergipark.org.tr/tr/pub/bujer/issue/33864/358732 adresinden erişilmiştir.

Öztürk, C. ve Kafadar, T. (2019). Fransız ve Türk okulu ortaokul öğrencilerinin değer algılarının karş1laştırılması. Eğitim ve Bilim, 44(198), 273-290. Doi: 10.15390/EB.2019.7837

Pehlivan, A., Aydın, İ. S. ve İnnalı, H. Ö. (2017). KKTC'de okutulan Türkçe ders kitaplarının değerler eğitimi üzerinden incelenmesi. Dil Eğitimi ve Araştırmaları Dergisi, 3(3), 164180. https://dergipark.org.tr/tr/pub/jlere/issue/32803/296510 adresinden erişilmiştir.

Reynold, R. (2018). Teaching humanities and social sciences in the primary school. https://www.oup.com.au/_data/assets/file/0010/132103/9780190311377_SC.pdf adresinden erişilmiştir.

Robb, B. (1998). What is values education - and so what? https://pdfs.semanticscholar.org/bbe0/35e99028e334d4c398d5c89132214ea57b26.pdf adresinden erişilmiştir.

Rokeach, M. (1973). The nature of human values. New York, NY: Free Press.

Savaşkan, V. (2017). Azerbaycan ve Türkiye'de okutulan edebiyat ders kitaplarındaki masalların aktardığı değerler açısından incelenmesi. Uluslararası Türkçe Edebiyat Kültür Ĕ̈itim Dergisi, $\quad 6(1)$, 439-454. http://www.tekedergisi.com/Makaleler/791744740_25sava\%c5\%9fkan.pdf adresinden erişilmiştir.

Schwartz, S. H. (1992). Universals in the content and structure of values: Theoretical advances and empirical tests in 20 countries. L. Berkowitz and M. P. Zanna (Eds.), (p. 1-65). In Advances in Experimental Social Psychology, San Diego, CA: Academic Press.

Schwartz, S.H. (2017). The refined theory of basic values. S. Roccas and L. Sagiv (Eds.), (p. 5174). In Values and behavior: Taking a cross-cultural perspective, Switzerland: Springer.

Schwartz, S. H., Cieciuch, J., Vecchione, M., Davidov, E., Fischer, R., Beierlein, C., Ramos, A., Verkasalo, M., Lönnqvist, J. E., Demirutku, K., Dirilen-Gumus, Ö. and Konty, M. (2012). Refining the theory of basic individual values. Journal of Personality and Social Psychology, 103(4), 663-688. Doi: 10.1037/a0029393

Şahin, Ö. ve Başgül, M. (2018). Ortaokul matematik ders kitaplarında sosyal değerler. Dicle Üniversitesi Ziya Gökalp Eğitim Fakültesi Dergisi, 34(2), 90-104. Doi: 10.14582/DUZGEF.1890

Şakiroğlu, Y. (2020). 6. sınıf Türkçe ders kitabının değer aktarımı bağlamında incelenmesi. Türkiye Eğitim Dergisi, 5(1), 145-161. https://dergipark.org.tr/en/download/articlefile/1111799 adresinden erişilmiştir.

Tulunay-Ateş, Ö. (2017). Türkiye'de değerler eğitimi uygulamalarının öğrencilere kazandırılması istenen olumlu özellikler üzerindeki etkisi. Değerler Eğitimi Dergisi, 15(34), 41-60. https://dergipark.org.tr/tr/pub/ded/issue/37287/430469 adresinden erişilmiştir. 
Ulusoy, K. ve Dilmaç, B. (2016). Değerler eğitimi. Ankara: Pegem Akademi.

UNESCO. (2002). Learning to be: A holistic and integrated approach to values education for human development: Core values and the valuing process for developing innovative practices for values education toward international understanding and a culture of peace. Bangkok: UNESCO Asia and Pacific Regional Bureau for Education.

Urfa, Ö. (2019). Türkiye ve Azerbaycan'daki anadil ders kitaplarında yer alan metinlerin değer iletimi bağlaminda incelenmesi. (Yüksek lisans tezi). https://tez.yok.gov.tr/UlusalTezMerkezi/ adresinden erişilmiştir (Tez No: 562918).

Uzun, M. ve Köse, A. (2017). Okul öncesi eğitimde değerler eğitiminin uygulanmasına yönelik öğretmen görüşleri. Bayburt Eğitim Fakültesi Dergisi, 12(23), 305-338. https://dergipark.org.tr/tr/pub/befdergi/issue/30012/305131 adresinden erişilmiştir.

Ültanır, G. (2000). Karşılaştırmalı eğitim bilimi. Ankara: Eylül.

Yazar, T., Özekinci, B. ve Lala, Ö. (2017). Öğretmen ve okul yöneticilerinin değerler eğitimi kavramına ilişkin metaforik algıları. Eğitimde Nitel Araştırmalar Dergisi, 5(3), 245-269. Doi: 10.14689/issn.2148-2624.1.5c3s11m

Yazıc1, M. (2014). Değerler ve toplumsal yapıda sosyal değerlerin yeri. Firat Üniversitesi Sosyal Bilimler Dergisi, 24(1), 209-223. https://dergipark.org.tr/tr/download/article-file/157368 adresinden erişilmiştir.

Yıldırım, A. ve Şimşek, H. (2016). Sosyal bilimlerde nitel araştırma yöntemleri. Ankara: Seçkin.

Yıldırım, S. G., Becerikli, S. ve Demirel, M. (2017). Farklı bakış açılarına göre sosyal bilgiler dersinde değerler eğitimi. Illkögretim Online, 16(4), 1575-1588. Doi: 10.17051/ilkonline.2017.342975

Yıldırım-Saçılık, M. (2019). Türkiye'nin ekonomik büyüme-kalkınma ve gelişme aşamalarında turizm öncü bir sektör olabilir mi?. Türk Turizm Araştırmaları Dergisi, 3(4), 1681-1697. Doi: $10.26677 /$ TR1010.2019.265

Zengin, M. (2017a). Bir uygulama modeli olarak Avustralya'daki okullarda değerler eğitimi. Uluslararası Sosyal Araştırmalar Dergisi, $10(52), \quad 866-883$. http://www.sosyalarastirmalar.com/cilt10/sayi52_pdf/5egitim/zengin_mahmut.pdf adresinden erişilmiştir.

Zengin, M. (2017b). Herkes için geçerli uygun değerleri belirlemek ve öğretmek mümkün mü? Değer eğitimi yaklaşımları bağlamında bir değerlendirme. Sakarya University Journal of Education, 7(2), 432-445. Doi: 10.19126/suje.307128

\section{EXTENDED ABSTRACT}

Problem: Human groups living in different parts of the world create their own cultures over the years. Along with language, religion, art, history, habits and traditions, values are among the components that generate the culture (Kafadar, 2019; Oğuz, 2011). Value is defined as "the abstract measure, superior quality, material and spiritual elements that include the social, cultural, economic and scientific values of a nation" (Turkish Language Association, 2020). In another definition, values are "socially desired concepts used to represent our goals" (Öztürk \& Kafadar, 2019, p.273). Values are also described as guides for distinguishing what is good and what is bad (Zengin, 2017b).

Each society purposes to transfer its culture and values to new generations. One of the most important ways in ensuring this transfer is values education. Values education is the activities performed by authorized or more experienced people to reveal the values underlying people's own 
behavior and the behavior of others, to reflect on these values, and to examine the effects of values on social welfare (Robb, 1998). In another definition, values education is an effort to teach the values of the society to new generations directly or indirectly by using various methods and techniques (Ulusoy \& Dilmaç, 2016). Values education is about moral thinking. The answers to the questions of how to be a person and how to behave are sought with values education. Social behavior rules and principles related to life and how to behave other people, and personality traits are the main subjects of values education (Halstead \& Pike, 2006).

Values and values education are phenomena that play a role in the transfer of moral and cultural heritage that regulate society, and individuals' relations with society. The social studies is one of the most important lessons in value transfer due to the fact that it is a lesson related to communities, contains historical and cultural elements, has an interdisciplinary structure and aims to adapt students to society (Kan, 2010). Since values are directly related to culture, tradition, lifestyle, social structure and perspective, different values may arise in different societies. There are some studies in the literature comparing Turkey with other countries in terms of values education. However, it has not been come across a study comparing Australia and Turkey.

The purpose of this study is to compare Turkish and Australian 5th grade social studies curriculum acquisitions in the context of values education. The comparison will be made using the value classification created by Schwartz et al. (2012). Research questions are below:

1. What is the distribution of Turkish and Australian 5th grade social studies curriculum acquisitions according to the value classification?

2. What are the similarities and differences between Turkish and Australian 5th grade social studies curriculum acquisitions in the context of openness to change higher order value?

3. What are the similarities and differences between Turkish and Australian 5th grade social studies curriculum acquisitions in the context of self-enhancement higher order value?

4. What are the similarities and differences between Turkish and Australian 5th grade social studies curriculum acquisitions in the context of conservation higher order value?

5. What are the similarities and differences between Turkish and Australian 5th grade social studies curriculum acquisitions in the context of self-transcendence higher order value?

Method: Qualitative research approach has been adopted in this study. The research method is document review. Descriptive approach was used to compare curricula. The data of the research were collected by document analysis technique. Turkish and Australian 5th grade social studies curricula, official reports about values education, and other scientific researches are the documents. In the analysis of the data, the value classification created by Schwartz et al. (2012) was used. This classification was preferred in the study because it was created by obtaining extensive data from 83 countries and considering the intercultural differences. In the classification of Schwartz et al. (2012), there are four higher order values. These are openness to change, selfenhancement, conservation, and self-transcendence. Openness to change includes self-direction, stimulation, and hedonism values. Self-enhancement includes achievement, power, and face values. Conservation includes security, tradition, and conformity values. Self-transcendence includes humility, universalism, and benevolence values. Descriptive analysis was used to analyze the data. First, themes were determined by considering the research questions. Then the data were read, and similar data were brought together to be able to obtain a logical whole. Last, the data were explained and compared.

Findings: Turkish 5th grade social studies curriculum acquisitions focuse on mostly conservation higher order value $(f=11)$. The least acquisition was found related to selftranscendence higher order value $(f=6)$. In terms of individual values, there are seven acquisitions related to security, five acquisitions related to power and self-direction, four acquisitions related to tradition and universalism, three acquisitions related to achievement, two acquisitions related to stimulation and benevolence, and one acquisition related to hedonism. There are not any acquisitions related to face, conformity, and humility. 
Australian curriculum acquisitions are mostly grouped under self-enhancement higher order value $(f=16)$. A limited number of acquisitions were found related to self-transcendence and openness to change higher order values $(f=3)$. In terms of individual values, there are 10 acquisitions related to achievement, six acquisitions related to power, five acquisitions related to security, three acquisitions related to tradition and self-direction, two acquisitions related to universalism, and one acquisition related to benevolence. There are no acquisitions that refer to the values of stimulation, hedonism, face, conformity, and humility.

Discussion and Suggestions: Turkish social studies curriculum acquisitions mostly refer to conservation higher order value which consists of security, tradition, and conformity. In Australian curriculum acquisitions, on the other hand, self-enhancement higher order value which consist of achievement, power, and face, is the most frequently cited. This finding indicate that Turkey's curriculum relatively places emphasis on raising decent and responsible citizens, and servicing to the society while Australian curriculum cares about individual development and skills.

Security and power values are at the forefront both Turkish and the Australian curriculum. This may be because the security value is seen as a prerequisite for teaching other values. Unless personal and social security is provided, it will not be possible to teach other values. Power value means to have an effect on resources and people. The reason for this value to come to the forefront may be the desire to teach how to effectively use resources which are getting scarce, and to gain the students economic awareness.

According to the results of the research, there are not enough acquisitions that address the self-transcendence higher order value in the 5 th grade social studies lesson curriculum. Therefore, the acquisitions could be updated to take into account self-transcendence values.

According to the results of the research, there are either no or insufficient number of acquisitions in respect to values of face, conformity, humility, hedonism, stimulation and benevolence in the 5th grade social studies curriculum. By taking these values into consideration, the acquisitions could be reconsidered. 